Karol Łopatecki

Uniwersytet w Białymstoku

k.lopatecki@uwb.edu.pl

\title{
Rola map i planów w działaniach taktycznych wojsk polskich i litewskich do początku panowania Stefana Batorego ${ }^{1}$
}

\begin{abstract}
The Role of Maps and Plans in the Tactics of Polish and Lithuanian Armies until the Beginning of the Rule of Stephen Báthory
\end{abstract}

In this paper, the author analyses cartographic activities that directly affected the course of an armed conflict. Classic instances of such activities include the production of documents for the purposes of a siege or the preparation of an army for a battle, as well as plans of setting a military camp or the upbuilding of defence fortifications in a city or a fortress. The author analyses them in the chronological order, beginning with the earliest mentions concerning the use of maps in tactic actions until 1576.

The first theoretician to have connected cartographic activity with military tactics was Szymon Marycjusz of Pilzno. He presented his theses in a work entitled De scholis seu academiis libri duo printed in 1551. The evidence collected indicates that

${ }^{1}$ Artykuł powstał $\mathrm{w}$ ramach projektu badawczego Narodowego Centrum Nauki Opus (nr 2014/15/B/HS2/01104) Zwiąki literatury polskiej i kartografii w XVI I pot. XVII w. 
in the first half of the $16^{\text {th }}$ century people did not know how to use cartography for tactical military purposes. Military large scale cartography had different methodological rudiments than medium scale or small scale maps. The fundamental methodological assumption in the creation of plans consisted in leaving the pictorial manner (of landscape topographic accounts) for the sake of making a circuit around the area drawn. This had been previously postulated by Stanisław Grzepski who referred to Albrecht Dürer, while descriptions of such a solution date back as far as to the accounts of Maciej Stryjkowski from the 1570s. The precision of large scale military maps required the use of mathematical knowledge (namely, geometry). A need emerged for a special professional group of people measuring the height, width and depth of objects. The application of mathematics in the army was postulated as early as in 1555 by Albrecht Hohenzollern, while a group of professional military engineers was first described by Stanisław Sarnicki in Księgi hetmańskie (where he refers to them as metator castrorum).

The use of cartography in the conduct of a siege in the Polish-Lithuanian Commonwealth began in the 1560s. It was then that Albrecht Hohenzollern made an exemplary isometric projection of a besieged city. The year 1568 brought a plan of the attack on the Uła castle made probably by Maciej Stryjkowski.

Keywords: tactics, war in the $16^{\text {th }}$ century, military cartography, renaissance theoreticians of military science, large-scale maps, city plans, military engineers

Wykorzystanie prochu podczas działań wojennych doprowadziło w szesnastowiecznej Europie do gwałtownych przeobrażeń określanych mianem rewolucji militarnej2. Rozwój artylerii postawił pod znakiem zapytania byt dotychczasowych fortyfikacji. Przeobrażenia w pierwszej kolejności dokonały się na terenie Półwyspu Apenińskiego w latach 1450-1534. Wprowadzenie bastei i bastionów oraz

${ }^{2}$ K. DeVries, Gunpowder Weaponry and the Rise of the Early Modern State, „War in History" 5 (1998), issue 2, s. 127-145.

3 J.R. Hale, The Early Development of the Bastion. An Italian Chronology, c. 1450 c. 1534, w: Europe in the Late Middle Ages, ed. J. Hale, J.R. Highfield, B. Smalley, London 1965, s. 466-494. Kolejne zasadnicze przemiany zaszły na terenie ogarniętych powstaniem Niderlandów - w latach 70. XVI wieku. Wówczas włoski system defensywny został przekształcony przez inżynierów Adriaana Anthoniszoona i Simona Stevina, co doprowadziło do stworzenia staroholenderskiej szkoły fortyfikacyjnej. 
zastosowanie artylerii doprowadziło w XVI stuleciu do bezprecedensowego $\mathrm{w}$ historii wojskowości przejścia od obrony pionowej do poziomej ${ }^{4}$. Zmienił się tym samym sposób zdobywania twierdz, działania dokładnie planowano, a ich realizacja wymagała przeprowadzenia długotrwałych prac oblężniczych ${ }^{5}$. Kluczowa dla obrony poziomej była doskonała znajomość terenu, na którym prowadzono oblężenia. To zaś spowodowało konieczność tworzenia map i planów na użytek działań taktycznych. Te nowe obowiązki przypadły nowo powstałej grupie zawodowej - inżynierom wojskowym ${ }^{6}$.

M.S. Kingra, The Trace Italienne and the Military Revolution During the Eighty Years' War, 1567-1648, „Journal of Military History” 57 (1993), no. 3, s. 434-437, 439.

${ }^{4}$ Charakterystyczne jest wykorzystanie nie tylko właściwości naturalnych terenu, ale i sztucznego kształtowania obszaru poza obrębem murów miast i twierdz. Wprowadzenie hydroinżynierii (systemu grobli, kanałów i fos) szczególnie widoczne jest w wojnie prowadzonej od 1568 roku na terenie Niderlandów. Zob. R. Szmytka, Walka z wiatrakami. Antyhiszpańskie powstanie w Niderlandach jako konflikt asymetryczny w perspektywie historii środowiskowej, „Prace Historyczne” 143 (2016), s. 677-681.

5 T.M. Nowak, Problem stosowania broni palnej przy obronie $i$ zdobywaniu umocnień przez wojska polskie w XVI-XVII w., "Studia i Materiały do Historii Wojskowości” 12 (1966), 1, s. 63-69. Por. T.F. Arnold, Fortifications and the Military Revolution: The Gonzaga Experience, 1530-1630, w: The Military Revolution Debate. Readings on the Military Transformation of Early Modern Europe, San FranciscoOxford 1995, s. 205 i nn.; D. Parrott, The Utility of Fortifications in Early Modern Europe: Italian Princes and Their Citadeles, 1540-1640, „War in History” 7 (2000), issue 2, s. 127-129 i nn.

${ }^{6}$ Uwagi o działalności inżynierów wojskowych dotyczą właściwie XVII i XVIII stulecia. B. Dybaś, Inżynier czy architekt? Uwagi o inżynierach wojskowych w XVII-wiecznej Rzeczypospolitej, „Barok” 7 (2001), nr 1, s. 153-164; K. Łopatecki, Prace kartograficzne wykonane na ziemiach Rzeczypospolitej przez szwedzkich inżynierów wojskowych w XVII stuleciu, „Studia i Materiały do Historii Wojskowości” 46 (2009), s. 55-80; T.M. Nowak, O zawodzie inżyniera wojskowego w Polsce XVII w., „Kwartalnik Historii Nauki i Techniki” 21 (1976), nr 3, s. 475-478; R. Nestorow, Jan Kampenhausen, inżynier na usługach hetmana Adama Mikołaja Sieniawskiego, w: Fides Ars Scientia. Studia dedykowane pamięci Księdza Kanonika Augustyna Mednisa, red. A. Betlej, J. Skrabski, Tarnów 2008, s. 315-326. Por. F. Westra, Nederlandse ingenieurs en de fortificatiewerken in het eerste tijdperk van de Tachtigjarige Oorlog, 
W niniejszym artykule analizuję działania kartograficzne, które w sposób bezpośredni miały wpływ na przebieg starcia zbrojnego. Przykładem takich prac jest stworzenie dokumentacji na potrzeby akcji oblężniczych czy też bitew, a także planów założenia obozu wojskowego lub rozbudowy założeń obronnych w mieście bądź twierdzy. Analizuję to zjawisko chronologicznie - od najwcześniejszych wzmianek dotyczących tego zagadnienia aż do roku 1576. Granica czasowa wiąże się z wyprawami Stefana Batorego na Gdańsk, Połock, Wielkie Łuki i Psków - podczas tych wypraw zauważalna jest już nowa jakość w wykorzystaniu kartografii w czasie wojen ${ }^{7}$. Obecnie najbardziej miarodajnym opracowaniem na ten temat, zawierającym również stan badań, jest monografia autorstwa Stanisława Alexandrowicza ${ }^{8}$.

Jako pierwszy na terenie Rzeczypospolitej kartografię z taktyką połączył Szymon Marycjusz z Pilzna w pracy z 1551 roku9. Zwrócił on uwagę na naukę geometrii, istotną „przy zakładaniu obozu, zajmowaniu okolicy, łączeniu i rozstawianiu oddziałów i innych zarządzeniach, których używamy w bitwie albo przy oblężeniu" ${ }^{10}$. Są to ważne, choć zdawkowe informacje. Autor nieco rozszerzył tę koncepcję w dalszej części tekstu. Upodmiotowił rolę miernictwa. Jest to „ta część filozofii, która się zajmuje matematycznymi wymiarami i figurami w przestrzeni”. Dzięki tej nauce można było prawidłowo przeprowadzić „działania przy oblężeniu, albo dobywaniu miast, ko-

1573-1604, Alphen aan den Rijn 1992, passim (s. 147-151 streszczenie w języku angielskim).

7 K. Buczek, Kartografia polska w czasach Stefana Batorego, „Wiadomości Służby Geograficznej" 7 (1933), z. 2, s. 69-121; K. Buczek, Dorobek kartograficzny wojen Stefana Batorego, „Wiadomości Służby Geograficznej” 8 (1934), z. 3, s. 3-15.

${ }^{8}$ S. Alexandrowicz, Kartografia Wielkiego Księstwa Litewskiego od XV do połowy XVIII wieku, Warszawa 2012, s. 157-208 (rozdz. VI: Początki kartografii wojskowej).

${ }^{9}$ S. Maricius, De scholis seu academiis libri duo, Kraków: Hieronim Szarffenberg, 1551.

${ }^{10}$ S. Marycjusz z Pilzna, O szkołach czyli akademiach ksiag dwoje, przeł. A. Danysz, oprac. H. Barycz, Wrocław 1955, s. 71. 
paniu rowów, sypaniu wałów, zakładaniu min, zwracaniu albo odwracaniu rzek, zataczaniu lub podnoszeniu machin, czyli kusz do ciskania, sprawianiu pułków, rozstawiania czat"11.

Na podstawie dzieła Szymona Marycjusza można zauważyć, że wykorzystanie wiedzy kartograficznej w działaniach taktycznych wymaga znacznej precyzji, nieporównywalnej z opracowaniem map na potrzeby operacyjne lub strategiczne.

Różnicę w metodologicznym podejściu do tworzenia map wielkoskalowych w porównaniu ze sporządzaniem map średnio- i małoskalowych można dostrzec w Księgach hetmańskich Stanisława Sarnickiego. Autor wskazywał, że tworzeniem tych drugich powinny się zająć osoby artystycznie uzdolnione, określa je mianem pictor (malarz) ${ }^{12}$. Inne, specjalne zadania przypisuje osobie określanej w pracy jako „miernik obozowy” (metator castrorum). Sarnicki wyjaśnia, że w wojsku osoba ta ma daleko szerszy zakres obowiązków niż zwykły mierniczy, który opanował jedynie „część geometryjej”.

Alie iże przypadają te potrzeby wiedzieć distancyją murów, szerokość wrót, okien i samej wieże, tedy tego nie zgadnie jeno geometra. Atożby takiego metatora trzeba, który by był geometrą. Przy obieraniu miesca obozowi przypada nie jednakej figury pliac, jeden bedzie płaski przestronny, drugi okrągły, drugi klinowaty. Rombus, romboides, isopleurus, skalenus i inne rozmaite. Atoż jako jedno z drugiem zrównać, wyrozumieć, żeby się wszyscy zmieścili, żeby na ewolucyją. Item gdy się każą rostąpić, konstypować, kondensować pliacu stawało. Item zgadnąć liczbę wojska nieprzyjacielskiego, wnet osumować i inne tem podobne rzeczy, tego żaden nie zgadnie jeno artificiosus metator co umie geometryją i geodezyją ${ }^{13}$.

Jest to pierwsza powstała na terenie Rzeczypospolitej wzmianka źródłowa o nowym zawodzie - inżynierze wojskowym. Autor postuluje wykorzystanie umiejętności inżynierów do oceny wysokości, szerokości i głębokości obiektów, rozmierzania i wyznaczania kwa-

11 Ibidem, s. 79.

12 S. Sarnicki, Księgi hetmańskie, oprac. M. Ferenc, Kraków 2015, s. 136-137.

13 Ibidem, s. 182-183. 
ter, ustawiania wojska, przygotowania planów oblężenia, ale również ocenienia sił nieprzyjaciela ${ }^{14}$.

Współcześni podkreślali konieczność połączenia wiedzy geometrycznej (co należy utożsamiać z miernictwem) oraz matematyki. Akcentował to Albrecht Hohenzollern w Ksiegach rycerskich powstałych w 1555 roku. Osoba przygotowana w tych dziedzinach wiedzy: „wiela figur a prędkiego obaczenia każdej rzeczy nauczyć się może, że oczyma chnetże to, co potrzeba wiedzieć obaczy, gdzieby siła mierzenia, jeżdżenia a biegania"15. Również wymieniony uprzednio Stanisław Sarnicki, opisując zawód matematyka, podkreślał, że powinien być to

[...] dobry kosmograf, geograf i topograf. [...] Tenże i geometryją, arytmetykę wedlie swej profesyjej doskonalie winien umieć, która do mierzenia daliekości, głębokości i wysokości rzeczy służy, co do strzeliania z dział, do dobywania miast jest niewymownie potrzebno ${ }^{16}$.

W historiografii przyjęta jest koncepcja łącząca rozwój kartografii $\mathrm{z}$ malarstwem ${ }^{17}$. Hipoteza ta wydaje się wiarygodna $\mathrm{w}$ przypad$\mathrm{ku}$ rozwoju szesnastowiecznych map wielkoskalowych. Na potrzeby cywilne prezentacja malarska niewielkiego obszaru była chętnie stosowana $^{18}$, jednakże jej zastosowanie w celach wojskowych mogło

14 Było to założenie przyjęte w wojskowości europejskiej XVII i XVIII wieku. W tym czasie jedną $\mathrm{z}$ najważniejszych powinności inżynierów wojskowych było wykonywanie planów i map na potrzeby armii. Kodeks wojskowy Piotra I z 1716 roku, oprac. i przeł. P. Krokosz, K. Łopatecki, Kraków-Oświęcim 2016, s. 115-116, 122-123.

15 Die Kriegsordnung des Markgrafen zu Brandenburg Ansbach und Herzogs zu Preussen Albrecht des Älteren - Königsberg 1555, Bd. 1-2, hrsg. von H.J. Bömelburg, B. Chiari, M. Thomae, Braunschweig 2006, s. 166.

16 S. Sarnicki, Ksiegi hetmańskie, s. 125.

17 M. Gębarowicz, Początki malarstwa historycznego w Polsce, Wrocław 1981, s. 17.

18 J. Gołaski, Kształtowanie się mapy wsi w Polsce do końca XVIII w. Studium nad geneza wielkoskalowej informacji kartograficznej, Wrocław 1969, s. 61-64. Autor używa określenia „pejzażowe przekazy topograficzne”. 
mieć katastrofalne skutki. Współcześni zauważyli, że reprezentacja wizualna nieoparta na wiedzy mierniczej prowadzi do błędnych ustaleń. Podkreślał to w swojej pracy dydaktycznej rektor Akademii Krakowskiej, twórca pierwszego polskiego podręcznika do geodezji i miernictwa, Stanisław Grzepski (1524-1570) ${ }^{19}$. Ze względu na wagę źródła pozwalam sobie zacytować dłuższy fragment:

Albertus Durarus ${ }^{20}[\ldots]$ mając jednego ucznia rozkazał malować zamek jeden i okoliczności jako pola i lasy przy tamtym zamku. Uczeń jako się już był wyćwiczył uczynić wszystko podług rozkazania. Durerus chcąc uczniowi pokazać, że do tego odrysowania, trzeba malarzowi doskonałem co więcej umieć, z tego miejsca gdzie uczeń malował, wziąwszy kartę odwiedzie się z uczniem, na insze opodal miejsce i patrząc na kartę na której przy zamku las był namalowany mówi do ucznia „Patrz na zamek, patrz na las jako od siebie są odległe, a tu na karcie wespołeś je namalował". Uczeń dziwuje się, nie wie co na to rzec, aż mu Albrecht Durer powie: „Wiedz, że o tym, że się też potrzeba uczyć widzieć i o widzeniu słuszny dać rozsądek, gdyż to insza rzecz jest z pewne[go] miejsca apparentiam rzeczy malować, a insza zaś położenie miejsc według tego proporcjej jako na ziemi leżą odrysować ${ }^{21}$.

19 S. Grzepski, Geometria, to jest miernicka nauka, po polsku krótko napisana $z$ greckich $i z$ łacińskich ksiąg, Kraków: Łazarz Andrysowic, 1566 (reprint: Warszawa 1861; wydanie krytyczne: S. Grzepski, Geometria to jest miernicka nauka, wstęp H. Barycz, K. Sawicki i A. Siudut, Wrocław 1957). Najstarszym łacińskojęzycznym podręcznikiem do geometrii wydanym w Koronie była praca Marcina Króla z Żurawicy (ok. 1422-1469). M. Król, Geometria praktyczna, wyd. L. Birkenmajer, Warszawa 1895; K. Sawicki, Pięć wieków geodezji polskiej, Warszawa 1964, s. 65-76; T.M. Nowak, Cztery wieki polskiej książki technicznej 1450-1850, Warszawa 1961, s. 16-18.

${ }^{20} \mathrm{~W}$ rękopisie Albertys Burerus - chodzi oczywiście o Albrechta Dürera (1471-1528). Zasady perspektywy zostały przedstawione w książce: A. Dürer, Underweysung der Messung, mit dem Zirckel und Richtscheyt, in Linien, Ebenen unnd gantzen corporen, Nürnberg, [b. dr.], 1525.

${ }^{21}$ Cyt. za: [J. Brożek], De Valentino Fontano et Grzepski, Biblioteka Kórnicka PAN, rkps 994, k. 102v.-103. Zob. również J. Brożek, Wybór pism, t. 1, oprac. H. Barycz, Warszawa 1956; J.K. Bogusławski, Życia sławnych Polaków krótko zebrane, t. 2, Wilno 1814, s. 59-60; Starożytności historyczne polskie, t. 1, wyd. A. Grabowski, Kraków 1840, s. 461-462. Fragment cytatu przytacza: T. Zarębska, Początki polskiego piśmiennictwa urbanistycznego, Warszawa 1975, s. 403. 
W konsekwencji już w latach 70. XVI wieku powszechnie przyjmowano, że obowiązkiem inżyniera wojskowego wykonującego wielkoskalowe plany jest obejście dookoła przedstawianego obszaru. Wspomina o tym Maciej Stryjkowski, który wykonując plany miast tureckich, nie rysował ich panoramy, lecz z „przeważną eksperyjencyją wożąc się w koło nich w bacie [łodzi - K.Ł.] z niemałym nakładem [...] samem wyrysował, iuxta regulas geometricas et cosmographicas, iż czytelnik jakoby tam sam był wszystko snadnie z pracej naszej obaczyć może"22.

W tym kontekście, warto przywołać wizerunek pierwszego malarza/kartografa wojskowego na ziemiach polsko-litewskich. Jest to postać namalowana na anonimowym obrazie Bitwa pod Orsza (il. 1). Kartograf jest przedstawiony w cywilnym ubraniu. Siedzi przy pniu złamanego drzewa i kadruje prawą dłonią pole bitwy. Zdzisław Żygulski przyjął, że mamy do czynienia $z$ autoportretem, a zamieszczenie go na obrazie świadczy o tym, że malarz był „istotnie bezpośrednim obserwatorem bitwy"23. Oczywiście możliwa jest i odwrotna interpretacja - artysta mógł przedstawić siebie na obrazie, nie będąc uczestnikiem działań wojennych. Za tą drugą koncepcją przemawiają ustalenia Marka Janickiego, który datuje powstanie dzieła na lata 40. XVI wieku, a zatem ponad ćwierć wieku po bitwie ${ }^{24}$.

${ }_{22}$ M. Stryjkowski, Kronika polska, litewska, żmudzka i wszystkiej Rusi, Królewiec: Georg Osterberg, 1582, k. A iijv.; zob. też B. Olszewicz, Geografia polska w okresie odrodzenia, Warszawa 1957, s. 32; Z. Wojtkowiak, Maciej Stryjkowski, dziejopis Wielkiego Księstwa Litewskiego. Kalendarium życia i działalności, Poznań 1990, s. 47.

${ }^{23}$ Z. Żygulski, „Bitwa pod Orszq” - struktura obrazu, „Rocznik Historii Sztuki” 12 (1981), s. 92.

${ }^{24}$ M. Janicki, Obraz Bitwa pod Orszą - geneza, datowanie, wzory graficzne a obraz bitwy „na Kropiwnej” $i$ inne przedstawienia batalistyczne $w$ wileńskim pałacu Radziwiłłów, w: Bitwa pod Orszą, red. M. Nagielski, Warszawa 2015, s. 221. 


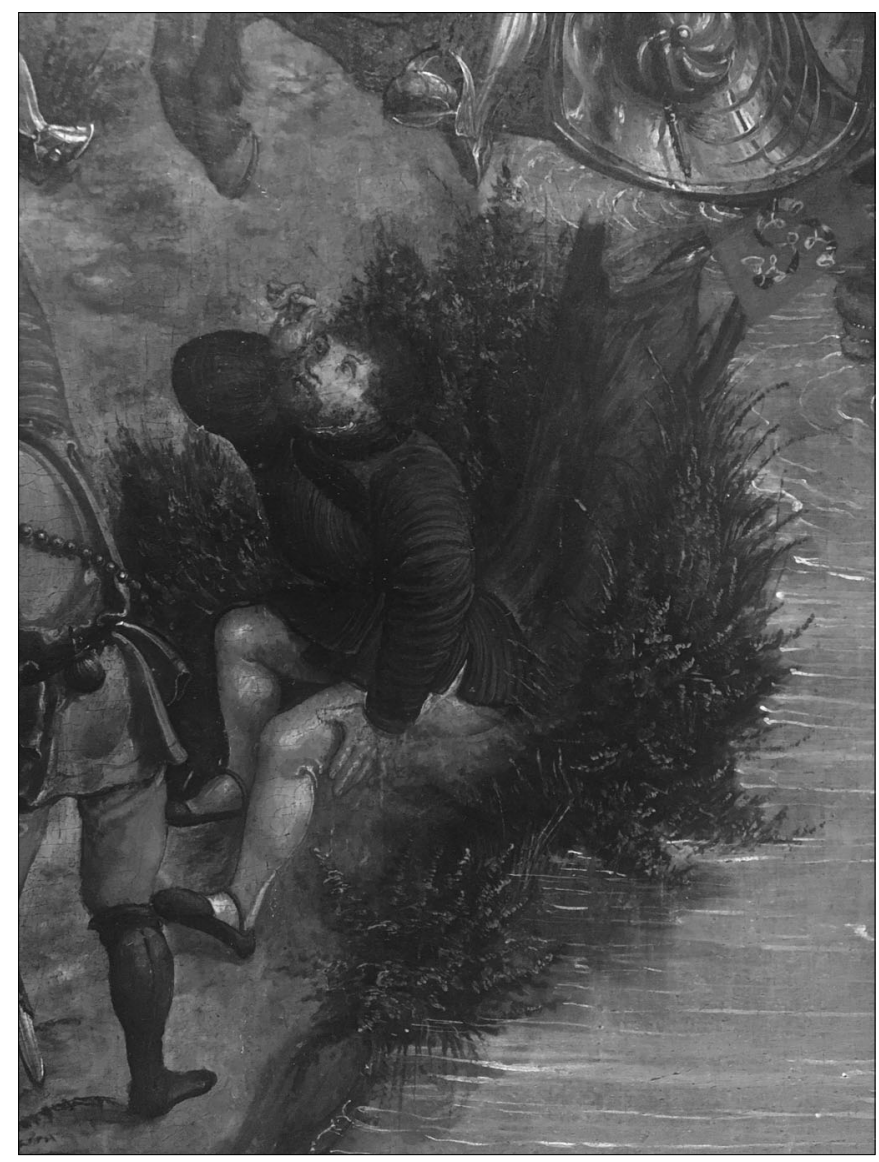

Il. 1. Malarz (kartograf) na polu bitwy, fragment z Bitwy pod Orsza (Muzeum Narodowe w Warszawie, nr inw. MP $2575^{25}$, fot. K. Łopatecki)

${ }^{25}$ Charakterystyczne na obrazie jest skierowanie w stronę malarza jednej z kopii z proporcem przedstawiającym trąby na czerwonym polu. Może to sugerować, że Janusz Świerczowski (łączony z tym proporcem: M. Janicki, Obraz..., s. 222) zabrał ze sobą osobę, która wykonała panoramę pola bitwy. Są to jednak trudne do udowodnienia sugestie. 
Niezależnie od przyjętej hipotezy obraz ukazuje działania pictora na polu bitwy w pierwszej połowie XVI wieku. Postać dokonuje wstępnych, dodajmy: statycznych, czynności, właściwych dla malarzy, tym samym postępuje wbrew przestrodze sformułowanej przez Dürera, a następnie Grzepskiego. Obraz ten stanowi dowód na to, że w pierwszej połowie XVI wieku nie potrafiono jeszcze w sposób prawidłowy wykonać wojskowych map wielkoskalowych. Mogły wówczas powstawać jedynie „pejzażowe przekazy topograficzne”. Dla porównania warto zestawić ten wizerunek $\mathrm{z}$ autoportretem umieszczonym na mapie wykonanej przez Fryderyka Getkanta (il. 2) ${ }^{26}$. Ich konfrontacja najlepiej obrazuje przemiany zachodzące w zawodzie od malarza do inżyniera wojskowego.

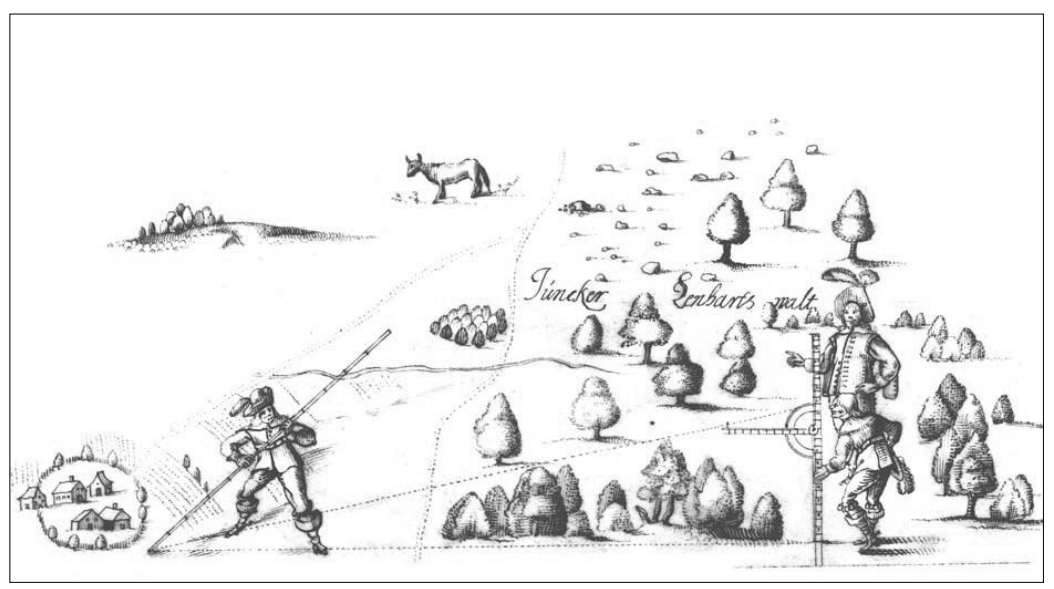

Il. 2. Autoportret Fryderyka Getkanta (Riksarkivet, Stockholm, Handritade kartverk, Bd. 28: Topographia practica. Conscripta et recognita per Fridericum Getkant mechanicum. Anno 1638, k. 4, fragment)

${ }^{26}$ K. Łopatecki, W. Walczak, Mapy i plany Rzeczypospolitej XVII w. znajdujace się $w$ archiwach $w$ Sztokholmie. Maps and Plans of the Polish Commonwealth of the $17^{\text {th }}$ c. in Archives in Stockholm, t. 1, Warszawa 2011, s. 100. 
Albrecht Dürer wspomina jedynie o rozpoznaniu całego terenu $\mathrm{z}$ różnych perspektyw, tak aby obszar przedstawiony na mapie był zbliżony do rzeczywistości. Ażeby osiągnąć większą precyzję, konieczne było zastosowanie narzędzi mierniczych. $\mathrm{Na}$ autoportrecie Fryderyka Getkanta widoczny jest między innymi pręt mierniczy (il. 2). Oprócz tego narzędzia posługiwano się sznurem, który nazywano wężyskiem (il. 3). Miał on około 43,2 m długości i składał się z 10 prętów (ok. $432 \mathrm{~cm}$ ). Dzięki temu podstawą mierzenia powierzchni był plac kwadratowy (również zwany wężyskiem), składający się ze 100 prętów kwadratowych (obszar o powierzchni $\left.1866,2 \mathrm{~m}^{2}\right)^{27}$. Istniejące miary były przydatne także w wojsku: na potrzeby planowania bitwy, przemarszu armii czy zakładania obozu. Albrecht Hohenzollern stworzył tablice, które pozwalały dowódcy szybko rozplanować oddziały w terenie. Jedno wężysko w tym układzie mieściło 920 pieszych rozdzielonych w 46 rzędów po 21 osób w każdym lub 648 jeźdźców w 36 rzędach ustawionych po 18 koni ${ }^{28}$. $\mathrm{W}$ innym miejscu książę obliczył, ile wozów potrzeba do otoczenia obozu rozłożonego na planie kwadratu. Przykładowo plac o boku $432 \mathrm{~m}$ (czyli o długości 10 sznurów) powinien składać się w pierwszej linii z 408 wozów, w drugiej 416, a w trzeciej 424 (linie liczono od środka), czyli w sumie konieczne było przygotowanie 1248 wozów ${ }^{29}$. O przydatności takiej tabeli świadczy to, że hetman koronny Jan Tarnowski pisał o konieczności wykonania obliczeń, czyli „spisku wszytki wozy wielkie, które mają $\mathrm{w}$ rzędziech stać, aby wiedział co w który rząd ma wozów położyć”30, przy czym wskazywał na ko-

${ }^{27}$ S. Grzepski, Geometria, to jest miernicka nauka..., k. Jiij. W zasadzie identyczne miary podaje: W. Maisel, Kaliska „Proporcyja łokci, prętów, morgów i włóki” z XVI w., „Kwartalnik Historii Kultury Materialnej” 17 (1969), nr 2, s. 259-260.

${ }_{28}$ Die Kriegsordnung des Markgrafen zu Brandenburg Ansbach..., s. 221-222, 230-233.

${ }^{29}$ [A. Hohenzollern], Kriegsordnung bin ich genannt, British Library, MS Harley, 1413, k. 38v.; Die Kriegsordnung des Markgrafen zu Brandenburg Ansbach..., s. 264-265.

${ }_{30}$ J. Tarnowski, Consilium rationis bellicae, oprac. T.M. Nowak, Warszawa 1987, s. $167,169$. 


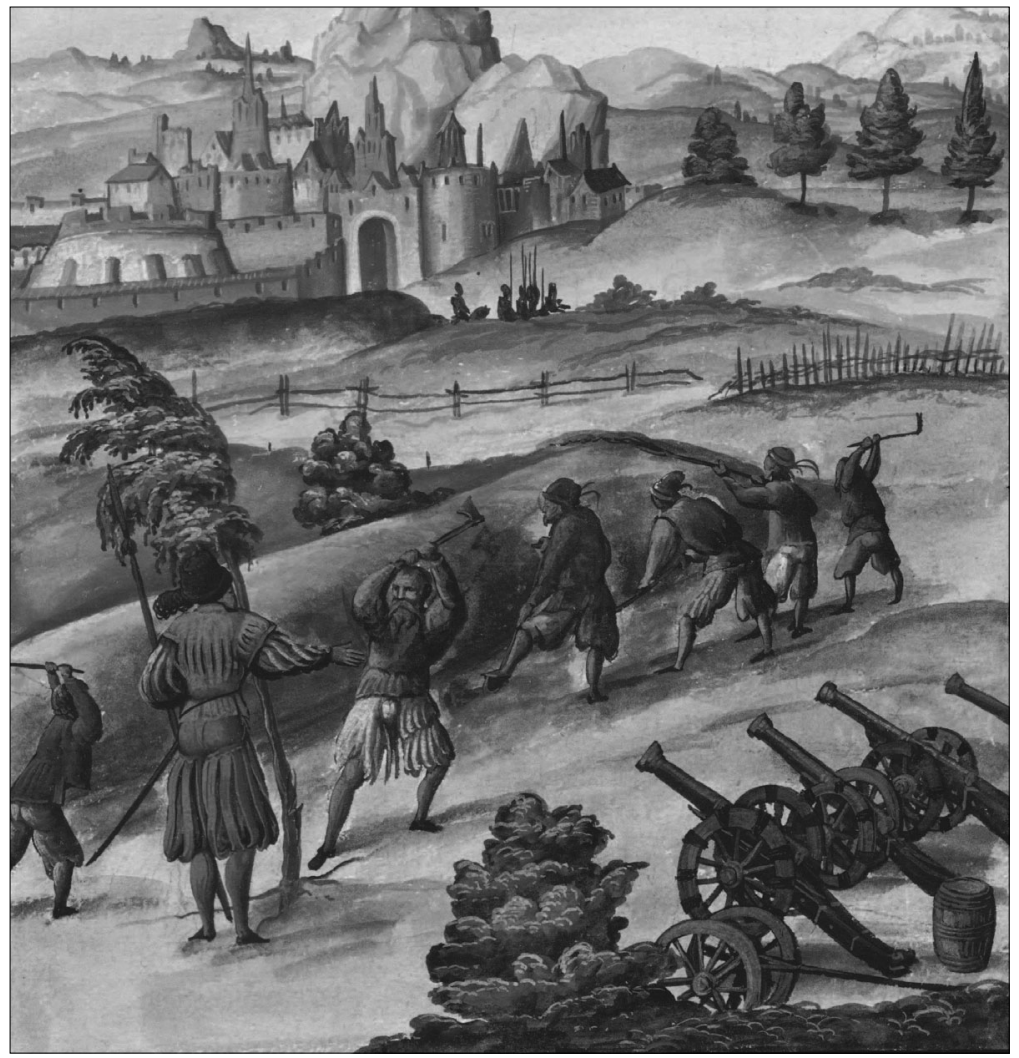

Il. 3. Wykorzystanie sznura przy pracach oblężniczych ([A. Hohenzollern], Kriegsordnung bin ich genannt wer kriegt, Staatsbibliothek zu Berlin, PreuBischer Kulturbesitz, Ms. boruss. fol. 1254, s. 281)

nieczność uwzględnienia różnej długości pojazdów ${ }^{31}$. Podobne zestawienia pojawiały się w całej Europie ${ }^{32}$.

31 Ibidem, s. 169.

32 Przykładowo: H. Lhor, Kriegs Feldbüchlin von allerlay Schlachtordnungen welches in zehen tail getailet und ist bey einem jegklichen Büchlin sein sondere lehr, Dilingen: Sebaldum Mayer, 1569. 
Uzupełnieniem kwestii sznura i wężyska jest ilustracja zamieszczona w pracy Kriegsordnung... Albrechta Hohenzollerna, w której przedstawiono wykorzystanie sznura przy zakładaniu stanowisk artyleryjskich naprzeciw nieprzyjacielskiego zamku (il. 3) ${ }^{33}$. Ukazano tu przykład wykorzystania w praktyce rozrysowanych uprzednio planów oblężniczych. Warto odnotować, że na potrzeby wojny z 1579 roku planowano zaopatrzyć się w „sznory do rozmiaru”, czyli właśnie liny miernicze ${ }^{34}$.

Niestety z XVI stulecia nie doczekaliśmy się powstałej w Rzeczypospolitej pracy poświęconej używanym przez inżynierów przyrządom. Jednak możemy być pewni, że posługiwali się przynajmniej busolą (ewentualnie kompasem - il. 5) i laską Jakubową, być może także astrolabium i kwadrantem ${ }^{35}$. O przedmiotach tych kilkakrotnie wspominał Stanisław Sarnicki w Ksiegach hetmańskich, autor wykonał nawet ich rysunek (il. 4$)^{36}$.

${ }_{33}$ [A. Hohenzollern], Kriegsordnung bin ich genannt wer kriegt, Staatsbibliothek zu Berlin, Preußischer Kulturbesitz, Ms. boruss. fol. 1254, s. 281. Por. K. Łopatecki, Twórczość wojskowa Albrechta Hohenzollerna. Uwagi nad trzema manuskryptami przypisanymi w latach 2009-2014 Albrechtowi Hohenzollernowi, „Odrodzenie i Reformacja w Polsce" 59 (2015), s. 163-188.

${ }^{34}$ Archiwum Główne Akt Dawnych, Archiwum Zamoyskich, sygn. 3112, k. 14.

${ }^{35}$ Szerzej o stosowanych w Europie narzędziach wykorzystywanych przez inżynierów i podróżników: A. Turner, Early Scientific Instruments. Europe 14001800, London 1987, s. 57-86.

${ }^{36}$ S. Sarnicki, Księgi hetmańskie, s. 157, 195-196, 402-403. Książę Albrecht Hohenzollern pracował nad tym zagadnieniem do końca swego życia (zm. 1568), ale problematyka ta nie została wyczerpana. Pozostała nam jedynie ilustracja przedstawiająca różnego rodzaju narzędzia wykorzystywane w wojsku. [A. Hohenzollern], Kriegsordnung bin ich genannt, British Library, MS Harley, 1413, k. 218 (księga X); P. Porter, A Fresh Look at Harley MS. 1413: 'A Book ... fairly written in the German or Switz language', „The Electronic British Library Journal” 8 (2009), s. 11. 


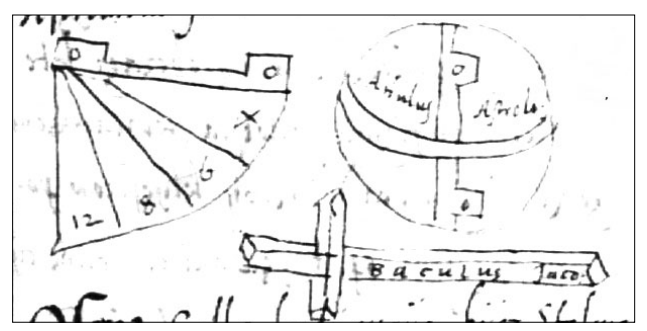

Il. 4. Kwadrant, astrolabium i laska Jakubowa według Stanisława Sarnickiego (Archiwum Główne Akt Dawnych, Archiwum Publiczne Potockich, rkps 325, t. 1, s. $192^{37}$, fot. Karol Łopatecki)

Posiadanie kompasów i busoli przez inżynierów łatwo jest udowodnić, jeżeli na planie lub mapie odnotowano kierunki geograficzne. Jeżeli takich oznaczeń brakuje, możliwe jest (choć niepewne), że nie używano takiego instrumentu.

Najdokładniejsze prace kartograficzne wykonano przy mapach wielkoskalowych mających w legendzie informację o skali (podziałka). Wówczas inżynier musiał wykorzystać inne istniejące narzędzia, między innymi laskę Jakubową, sznury i pręty miernicze (il. 6).

Teoretycy wojskowości nie doprowadzili do rewolucyjnej zmiany w świadomości elit szlacheckich. Przemiany następowały, choć były raczej powolne. Warto podkreślić, że najstarsza znana w Rzeczypospolitej instrukcja peregrynacyjna, w której ojciec zlecił synowi gruntowną naukę kartografii, pochodzi dopiero z 1602 roku. Wówczas starosta lubelski Piotr Myszkowski nakazał synowi naukę geometrii, miernictwa i kartografii, co miało zostać wykorzystane między innymi w wojsku ${ }^{38}$.

37 W rękopisie przechowywanym w Bibliotece Jagiellońskiej (rkps 171, s. 123) brak rysunku przedstawiającego laskę Jakubową.

${ }^{38}$ Dwa pedagogiczne traktaty polskie XVI-XVII wieku z Cesarskiej Biblioteki Publicznej w Petersburgu, wyd. Z. Bujakowski, w: Archiwum do dziejów literatury $i$ oświaty $w$ Polsce, t. 14, Kraków 1914, s. 346: „a geometra normam unius atque 


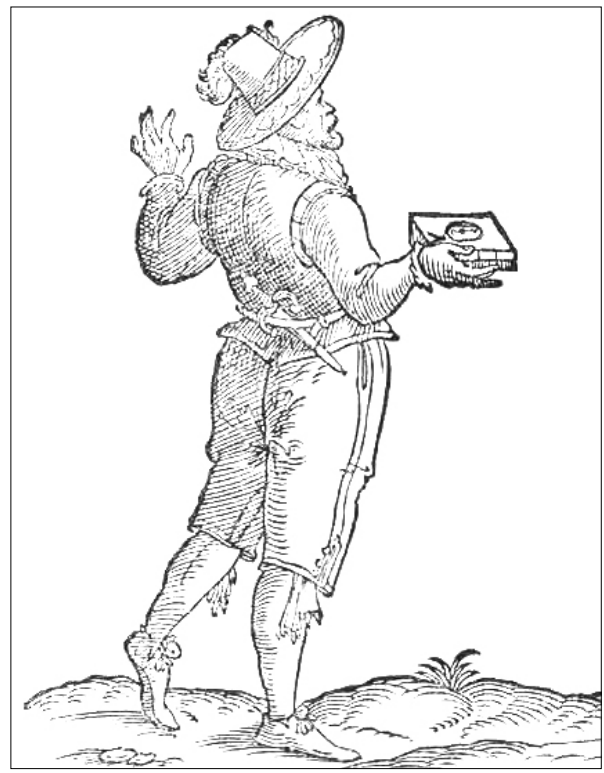

Il. 5. Inżynier wykorzystujący kompas przy pracy kartograficznej (P. Pfinzing, Methodus Geometrica, Nürnberg: Valentin Fuhrmann, 1598, przed k. 15, https://books.google.pl/books?id=WbtWEC4xxkEC\&printsec=front cover $\& \mathrm{hl}=\mathrm{pl} \&$ source $=\mathrm{gbs} \_g e \_s u m m a r y \_r \& c a d=0 \# \mathrm{v}=$ onepage $\& \mathrm{q} \& \mathrm{f}=$ false, dostęp: 1.12.2017)

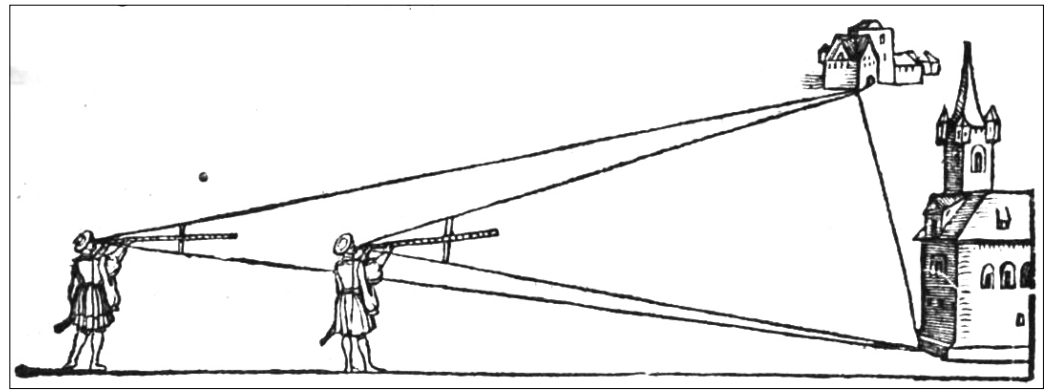

Il. 6. Wykorzystanie laski Jakubowej w pracach kartograficznych (P. Apian, Instrument-Buch, Ingolstadt: [G. \& P. Apian], 1533, k. N v., https://reader. digitale-sammlungen.de/de/fs1/object/display/bsb10806474_00005.html, dostęp: 4.12.2017) 
Niestety, wszystkie znane źródła wojskowej kartografii wielkoskalowej do końca panowania Stefana Batorego nie są ani orientowane, ani nie zawierają podziałki odległości. Być może świadczy to o braku wykorzystania wyżej opisanych narzędzi w tym okresie. Niemniej jednak istniała świadomość ich przydatności - przynajmniej wśród teoretyków.

Prawdopodobnie pierwszą czynnością związaną z działalnością wojskową, która wymagała posiadania umiejętności właściwych inżynierowi wojskowemu, było rozmierzenie i zaplanowanie obozu. Akcentował to Jan Tarnowski i w tym celu przygotował nawet specjalny plan, który miał stanowić wzorzec do zastosowania w praktyce. Niestety, nie zachował się on do naszych czasów ${ }^{39}$. Jak istotne i trudne zadanie wiązało się z założeniem obozu, barwnie opisuje Jan Piotrowski w okresie wyprawy Stefana Batorego na Psków:

Ale to gorsza, że nie masz, ktoby obóz toczył; był tak rok [temu - K.Ł.] Rembowski niejaki z Rusi, co ji dobrze toczył; nic mu nie dali za to, więc go nie masz teraz. P. Oboźny się z P. Roszkowskim podjęli, przy nich też komornik Sulimowski, siestrzanek onego Laskowskiego z kępiatą głową; nie wiem, sprostają li temu ${ }^{40}$.

alterius instrumenti ad locorum intervalla metienda, ad militaria munia obeunda, ad tormenta explodenda, fines regundos, aquas deducendas et caetera id genus manu conficienda percipiat; ab eodem geographiae elementis et tabularum doctrina instruatur". Por. B. Olszewicz, Wzmianki o znaczeniu map w literaturze polskiej XVI wieku, „Acta Universitatis Wratislaviensis. Studia Geograficzne” 9 (1963), s. 138.

${ }^{39}$ J. Tarnowski, Consilium..., s. 167: „Aby ten, kto będzie obóz kładł, wiedział to wszystko, na co trzeba baczność mieć a plac między rzędy ostawiać wozami, gdzie mają stać namioty, kuchnie, konie u kreptuchów, rydwany, kolasy, piczne wozy tak, jako to przy wymalowaniu obozu napisano, wiele łokci który plac w sobie mieć ma”. Por. T. Zarębska, Początki polskiego piśmiennictwa..., s. 243-244.

${ }^{40}$ J. Piotrowski, Dziennik wyprawy Stefana Batorego pod Psków, wyd. A. Czuczyński, Kraków 1894, s. 62. 
Charakterystyczne, że do pomocy przydano Sulimowskiego, który w kampanii wielkołuckiej zajmował się kartografiąa ${ }^{41}$. Obawy księdza Piotrowskiego były uzasadnione. Kompromitacją między innymi zakończyło się zatoczenie obozu pod Pskowem 28 sierpnia 1581 roku: „P. Oboźny Roszkowski, rotmistrz, komornik Sulimowski wziąwszy to zadanie na się, nie wiedzieli, gdzie trzy" ${ }^{42}$.

Miernictwo i kartografię w działaniach taktycznych wykorzystywano także przy rozplanowaniu oddziałów przed bitwą, czyli sporządzeniu tak zwany ordre de bataille. Oczywiście ustawienie wojsk nie mogło być przypadkowe i stanowiło jedną $\mathrm{z}$ najważniejszych decyzji taktycznych hetmana. Wydaje się niemal pewne, że plan rozmieszczenia wojsk przed bitwą był rozrysowywany przez głównodowodzącego, a następnie przekazywany dowódcom poszczególnych jednostek. Powstałe w wyniku działań wojennych materiały wykorzystywane były następnie w celach dydaktycznych i informacyjnych $^{43}$.

Sam plan szyku wojsk nie ma jeszcze wiele wspólnego z kartografią, gdyż nie odnotowuje on uwarunkowań terenowych. Takie uproszczone założenia znane są z początków XVI stulecia. Do najwcześniejszych należą datowany na rok 1509 plan szyku wojsk pospolitego ruszenia oraz dwa rozplanowania oddziałów zaciężnych na potrzeby wojny z zakonem krzyżackim (1520). W tym drugim przypadku pierwszy plan dotyczył ustawienia wojsk w walnej bitwie,

${ }^{41}$ Archivio Segreto Vaticano, Segreteria di Stato, Polonia, sygn. 15A, k. 88; K. Buczek, Dorobek kartograficzny wojen Stefana Batorego, s. 4-5; S. Alexandrowicz, Rozwój kartografii Wielkiego Księstwa Litewskiego od XV do połowy XVIII wieku, Poznań 1989, s. 191-192.

42 J. Piotrowski, Dziennik wyprawy..., s. 64.

${ }^{43}$ Zob. plan bitwy pod Kircholmem z 1605 roku wykonany przez Józefa Naronowicza-Narońskiego i Erika Dahlberga: Biblioteka Uniwersytetu Warszawskiego, rkps 1954, k. 144; A. Hniłko, Plan bitwy pod Kircholmem Józefa Naronowicza-Narońskiego z r. 1659, „Przegląd Historyczno-Wojskowy” 7 (1934), z. 1, s. 126-133; M. Balcerek, Liczebność, skład i szyk wojska hetmana litewskiego Jana Karola Chodkiewicza w bitwie pod Kircholmem na ordre de bataille Erika Dahlberga, „Zapiski Historyczne. Kwartalnik poświęcony historii Pomorza" 74 (2009), z. 3, s. 7-23. 
drugi prezentuje obronę obozu w razie nocnego ataku ${ }^{44}$. Dokumenty te zachowały się w kopiach wykonanych w drugiej połowie XVI wieku. Dla wojsk litewskich analogiczne plany są późniejsze: z 1564 roku pochodzi plan szyku wojsk stacjonujących pod Połockiem, a o trzy lata późniejszy jest rozkład służby ziemskiej i wojsk zaciężnych zebranych na wyprawę radoszkowicką ${ }^{45}$. Oczywiście najwięcej uwagi temu zagadnieniu poświęca Albrecht Hohenzollern, umieszczając w dziele Kriegsordnung... z 1555 roku 42 pięknie iluminowane plany szyku wojskowego oraz trzy plany obozów wojskowych (il. 7a i 7b) ${ }^{46}$. Dodać wypada, że książę skrupulatnie zbierał z całej Europy plany umocnień oraz szyków bojowych ${ }^{47}$. Do najważniejszych źródeł uzyskanych przez księcia pruskiego należy zaliczyć wysłany przez Jana Tarnowskiego w 1544 roku plan szyków tureckich ${ }^{48}$.

${ }^{44}$ Sprawa przeciwko mistrzowi pruskiemu tak była udziełana gdy była miała bydź bitwa z Niemcy przeciw ich zbrojnym, pieszym i jeznym i działom, Biblioteka Narodowa, sygn. 6609, k. 28; Sprawa gdy była przyszła przygoda w nocy na wojsko, Biblioteka Narodowa, sygn. 6609, k. 28v.

${ }^{45}$ Szyk pod Połockiem, Biblioteka Narodowa, sygn. 6609, k. 29-30; Тым обычаем в (ш)ыку гуфы стояли, Archiwum Główne Akt Dawnych, Dokumenty pergaminowe, rkps 7789; Por. G. Lesmaitis, Lietuvos Didžiosios Kunigaikštystès kariuomenés apžiüros Radaškovičiuose (1567) schema, „Lietuvos istorijos metraštis” (2010), z. 1 (wyd. 2011), s. 125-132.

${ }^{46}$ Uszykowania wojsk $\mathrm{z}$ nieistotnymi zmianami przedstawione było $\mathrm{w}$ trzech rękopisach: A. Hohenzollern, Kriegsordnung bin ich genannt, Staatsbibliothek zu Berlin, Preußischer Kulturbesitz, Ms. boruss. fol. 441; A. Hohenzollern, Księgi o rycerskich rzeczach a sprawach wojennych, przeł. M. Strubicz, Biblioteka Książąt Czartoryskich w Krakowie, rkps 1813; [A. Hohenzollern], Kriegsordnung bin ich genannt, British Library, MS Harley 1413.

${ }_{47}$ J. Voigt, Des Herzogs Albrecht Kriegsstudien und Kriegsanstalten, „Neue PreuBische Provinzialblätter” Serie III (Königsberg) 4 (1859), H. 1, s. 19-20.

${ }_{48}$ T.M. Nowak, Polska wersja „Porządku wojennego” Albrechta na tle stosunków polsko-pruskich, w: Die Kriegsordnung des Markgrafen zu Brandenburg Ansbach..., s. 149. Plan ustawienia wojsk tureckich nie przetrwał. W polskiej literaturze został wydrukowany w 1569 roku schemat obozu tureckiego. M. Bielski, Sprawa rycerska wedlug postępku i zachowania starego obyczaju rzymskiego, greckiego, macedońskiego i innych narodów pierwszego i niniejszego wieku tak pogańska jako i krześcijańska $z$ rozmaitych ksiag wypisana ku czytaniu i nauce ludziom rycerskim pożyteczna, 

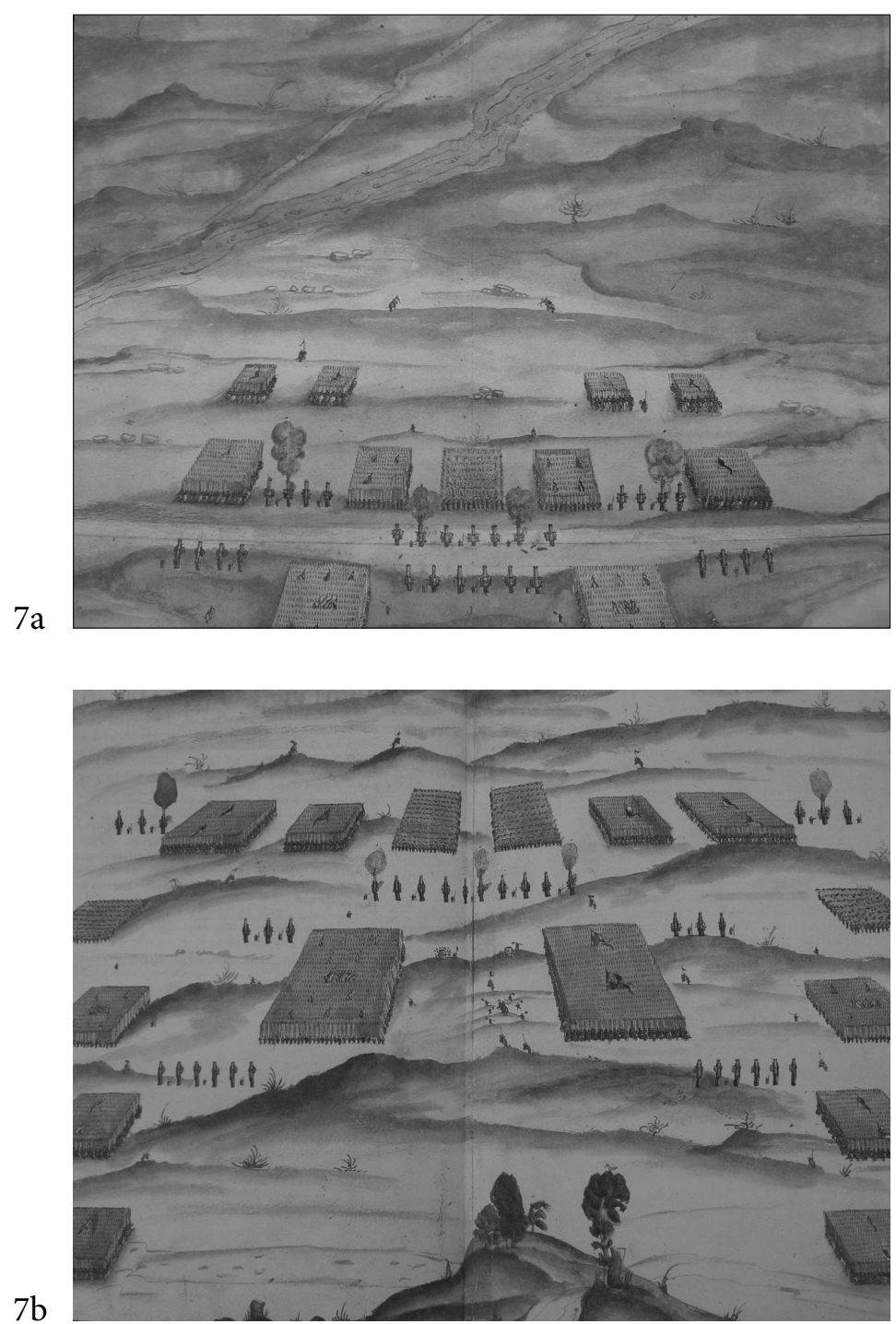

Il. 7a, 7b. Ustawienie wojska w świetle pracy Albrechta Hohenzollerna Kriegsordnung bin ich genannt (Staatsbibliothek zu Berlin, Preußischer Kulturbesitz, sygn. Ms. boruss. fol. 441, figura 9 i 23, fragmenty) 
Należy odnotować, że na ilustracjach zamieszczonych w Kriegsordnung... (il. 7a i 7b) występują co prawda drzewa, niewielkie wzniesienia terenu, drogi, grunty orne, ale w żadnym przypadku układ wojsk nie jest dostosowany do uwarunkowań terenu. Nie znaczy to, że książę tych elementów nie zauważał ${ }^{49}$.

Ustawienie wojsk prezentuje również Marcin Bielski w wydanej w 1569 roku Sprawie rycerskiej (il. 8) ${ }^{50}$. Umieszczone tam ilustracje zostały wykonane w konwencji schematów ułożonych za pomocą różnych liter. Pod względem kunsztu wykonania odbiega to radykalnie od ilustracji stworzonych na potrzeby księcia pruskiego. Teresa Zarębska uznała te założenia „za odważną próbę rysowania układów przestrzennych, która zapoczątkowała [...] nowy typ ilustracji: dwuwymiarowy schemat rozplanowania, a raczej jego wariant, budowany z liter"51. Rzeczywiście wobec dominującego rzutu izometrycznego na planach kartograficznych jest to rozwiązanie rzadkie ${ }^{52}$. Ukazuje ono możliwości prezentacji przestrzeni w dwóch wymiarach.

Kraków: Mateusz Siebeneicher, 1569, k. 55v. Szyk wojsk tureckich przygotował również Maciej Stryjkowski podczas swojej wyprawy dyplomatycznej do Porty Otomańskiej z lat 1574-1575. M. Stryjkowski, O wolności Korony Polskiej i Wielkiego Księstwa Litewskiego a o srogim zniewoleniu inszych królestw pod [...] jarzmem tureckim, Kraków 1575, s. 43.

${ }^{49}$ Die Kriegsordnung des Markgrafen zu Brandenburg Ansbach..., s. 237: „naprzód gdy się ku potykaniu z nieprzyjacielem przygotowują [...] na dobrem baczeniu zawsze [...] potrzeba jest: [...] słońce wiatry, prochy, wody, rzeki, bagniska, doły i góry". Por. T. Zarębska, Początki polskiego piśmiennictwa..., s. 233-238.

${ }_{50}$ M. Bielski, Sprawa rycerska..., k. 19, 21, 22v., 23, 23v., 25, 30, 32-34, 35, 71-72.

51 T. Zarębska, Początki polskiego piśmiennictwa..., s. 251.

${ }^{52}$ Analogiczne rozwiązanie zastosował Stanisław Sarnicki w dziele Księgi hetmańskie: Archiwum Główne Akt Dawnych, Archiwum Publiczne Potockich, rkps 325, t. 1, s. 310, 323-329, 331, 408, 410-417, 505. Pierwowzór takich rzutów: [G.B. Della Valle], Vallo libro continente appertinente [...], Vineggia: Piero Ravano, 1535 , k. 30 i nn. 


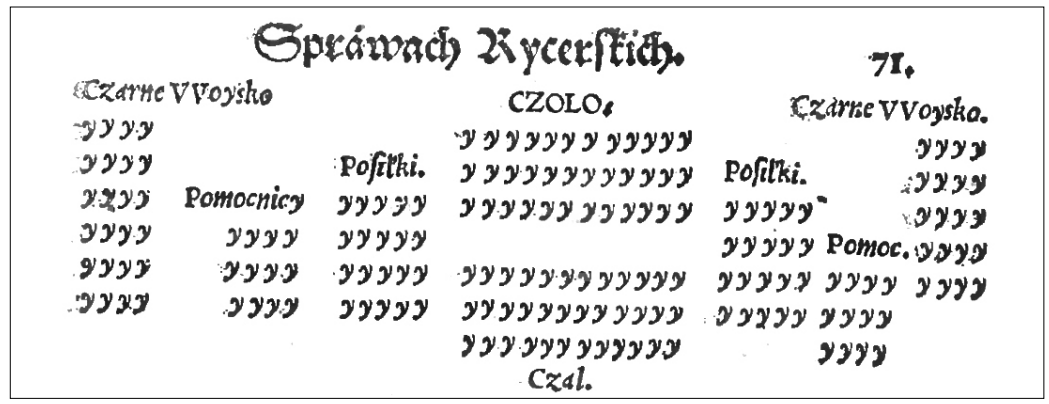

Il. 8. Plan ustawienia wojska polskiego przedstawiony przez Marcina Bielskiego (M. Bielski, Sprawa rycerska według postępku i zachowania starego obyczaju rzymskiego, greckiego, macedońskiego i innych narodow pierwszego i niniejszego wieku tak pogańska jako i krześcijańska z rozmaitych ksiag wypisana ku czytaniu i nauce ludziom rycerskim pożyteczna, Kraków: Mateusz Siebeneicher, 1569, k. 71, https://www.dbc.wroc.pl/dlibra/publication/5028/edition/4806, dostęp: 5.12.2017)

Jakościowa zmiana w ordre de bataille następuje wówczas, gdy szyk wojska dostosowany jest do warunków hydrogeograficznych ${ }^{53}$. Najwcześniejsze tego typu przedstawienie odnajdujemy u Stanisława Sarnickiego (il. 9). W swojej Księdze hetmańskiej przedstawia trzy uszykowania wojsk polsko-litewskich ${ }^{54}$. Pierwsze to schematyczne rozlokowanie hufów polsko-litewskich w bitwie pod Grunwaldem. Zostało na nim zaznaczone wzgórze, las oraz zgrupowania wojsk

53 Na uwzględnienie warunków terenowych pola bitwy zwracał uwagę Carl von Clausewitz, O wojnie. Księga 1-5, przeł. A. Cichowicz, L. Koc, Warszawa 1958, s. 103-104. „Teren [...] mógłby, ściśle biorąc, nie mieć żadnego wpływu, gdyby bitwę wydawano na zupełnie niepokrytej płaszczyźnie. W okolicach stepowych jest tak rzeczywiście, ale w krajach cywilizowanej Europy jest to prawie tylko wyobrażenie urojone. U ludów cywilizowanych bitwa bez wpływu terenu jest prawie nie do pomyślenia”.

54 Szerzej o planach sytuacyjnych wykonanych przez Stanisława Sarnickiego: T. Zarębska, Początki polskiego piśmiennictwa ..., s. 260-270. 


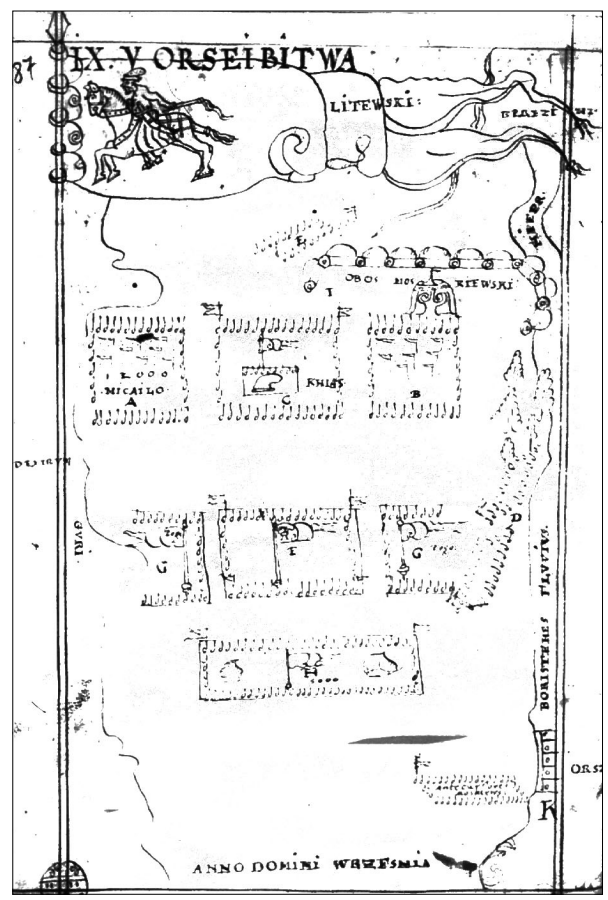

Il. 9. Plan bitwy pod Orszą według Stanisława Sarnickiego (S. Sarnicki, Księgi hetmańskie, Archiwum Główne Akt Dawnych, Archiwum Publiczne Potockich, rkps 325, t. 1, s. 387, fot. Karol Łopatecki)

tatarskich, ruskich, litewskich i polskich. Rysunek został przygotowany na podstawie ustnych i pisanych relacji. Autor przedstawił również bitwę pod Obertynem z 1531 roku, zabrakło tu jednak wyróżniających elementów topograficznych ${ }^{55}$. Najbardziej interesujący jest plan bitwy pod Orszą rozegranej w 1514 roku (il. 9). Ukazano na nim wzniesienia, położenie rzeki Dniepr, przez którą przerzucono most pontonowy, odnotowano położenie miasteczka Orsza oraz, co

55 S. Sarnicki, Księgi hetmańskie, s. 351-358, 367-373; idem, Księgi hetmańskie, Archiwum Główne Akt Dawnych, s. 373, 394. 
często pomijano, rzekę Kropiwnę, znajdującą się na wysokości taboru moskiewskiego. Warto dodać porośnięty lasem brzeg Dniepru, za którym ulokowały się, czy raczej ukryły, dwa niewielkie hufy litewskie. Przedstawienie jest o tyle interesujące, że w zestawieniu z omawianym wyżej, monumentalnym obrazem Bitwa pod Orszą $a^{56}$ może sugerować, iż na miejscu rzeczywiście znajdował się artysta, który wykonał ogólny plan bitwy ${ }^{57}$.

Carl von Clausewitz (1780-1831) zwracał uwagę, że świadome działania taktyczne najwcześniej zaczęły się uzewnętrzniać w sztuce oblężniczej ${ }^{58}$. Rzeczywiście, rozpoczynając oblężenie, należało w pobliżu założyć obóz, który miał stać się domem dla kilku (nawet kilkunastu) tysięcy żołnierzy przez kilkanaście tygodni. Trzeba było wykonać plany obleganej fortyfikacji oraz zaplanować działania oblężnicze, a także zabezpieczyć się na wypadek nadejścia odsieczy dla twierdzy. Szesnastowiecznym teoretykiem, który doskonale rozumiał nowe zadania stawiane przed głównodowodzącym, był Albrecht Hohenzollern. W swojej pracy podkreślił konieczność dokładnego zbadania „położenia zamku”, co miało pomóc ocenić jego mocne i słabe strony ${ }^{59}$. W latach 60 . XVI wieku książę pruski przygotował nawet plan, który miał być wzorcowym założeniem kartograficznym, uwzględniającym wszystkie istotne dla wojska elementy ${ }^{60}$. Źródło to stanowi przykład rzutu izometrycznego, czyli trójwymiarowego odwzorowania na płaszczyźnie (il. 10).

56 S. Herbst, M. Walicki, Obraz bitwy pod Orszą. Dokument historii sztuki i wojskowości XVI w., „Rozprawy Komisji Hist[orii] Sztuki i Kultury” (Warszawa) 1 (1949), s. 33-67; J. Białostocki, Zagadka „Bitwy pod Orsza”, „Biuletyn Historii Sztuki” 17 (1955), nr 1, s. 80-98; Z. Żygulski, „Bitwa pod Orsza”..., s. 85-132; M. Janicki, Obraz..., s. 173-200.

57 Warto dodać, że źródła ikonograficzne oraz pisane pozwalają badaczom na ustalenie dokładnego miejsca bitwy. А. Казакоў, Дзе адбылася Аршанская бітва 1514 2.?, „Герольд Litherland” 20 (2014), s. 4-29.

58 C. von Clausewitz, O wojnie..., s. 91-92.

59 Die Kriegsordnung des Markgrafen zu Brandenburg Ansbach..., s. 177-178, 236.

60 Szerzej o ostatnim, niedokończonym dziele Albrechta Hohenzollerna: K. Łopatecki, Twórczość wojskowa Albrechta Hohenzollerna..., s. 163-188. 


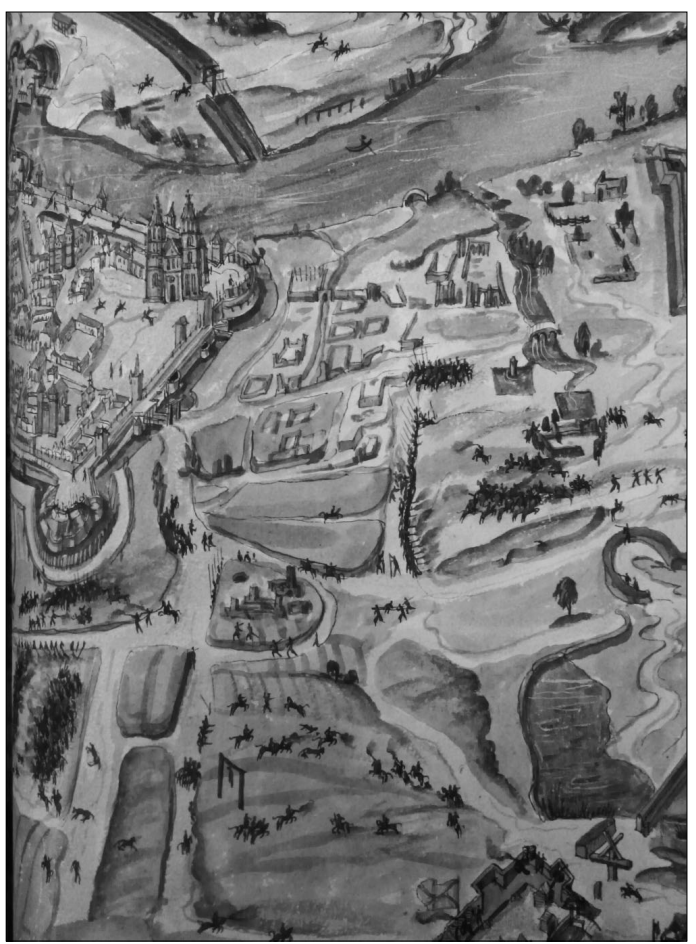

Il. 10. Schematyczny plan oblężenia miasta wykonany przez Albrechta Hohenzollerna, fragment ([A. Hohenzollern], Kriegsordnung bin ich genannt, British Library, MS Harley, 1413, k. 138)

Innym autorem piszącym o konieczności przygotowania map na potrzeby prowadzonych działań oblężniczych był Stanisław Sarnicki. Autor informował, że „miasta, zamki, których mają situm loci przedtem maliarze malują, że wczas o tem radzą, skąd by opugnacyją onę począć"61. Wykorzystanie źródeł kartograficznych podczas narady

${ }^{61}$ S. Sarnicki, Księgi hetmańskie, s. 137. Por. T. Zarębska, Początki polskiego piśmiennictwa..., s. 256; M. Gębarowicz, Początki malarstwa..., s. 18. 
wojennej potwierdzają również relacje dotyczące zdobycia zamku Uła w 1568 roku, o czym szerzej w dalszej części artykułu.

Sarnicki w Księgach hetmańskich zwraca również uwagę na dzieło Georga Brauna i Fransa Hogenberga Civitates orbis terrarum ${ }^{62}$, które miało być doskonałym źródłem wiedzy o stanie fortyfikacji poszczególnych miast („Acz teraz są księgi wielkie kędy właśnie miasta przedniejsze wykontrefektowano, mury, wały, baszty i inne propugnacula nic nie zostawiając jakmiarz" ${ }^{33}$ ). Co prawda w zamieszczonych ilustracjach dominuje ujęcie panoramiczne ${ }^{64}$, niemniej jednak znajdują się tam liczne plany ukazujące - dzięki rzutowi izometrycznemu stan fortyfikacji miejskich, układ miejski oraz najbliższe otoczenie miasta. Przykładem tego są przedstawione w pierwszym tomie plany miast: Antwerpii (zob. il. 11), Ankony, Amsterdamu, Akwizgranu, Augsburga, Bordeaux, Brugii, Brukseli, Cagliari, Kairu, Cascais, Kolonii, Famaugusty, Frankfurtu nad Menem, Gandawy, Gothy, Londynu, Lionu, Magdeburga, Messyny, Mediolanu, Neapolu, Nimes, Paryża, Rodosu, Rzymu, Strasburga, Utrechtu, Valletty, Wenecji, Wittenbergi i Würzburga.

Jakość wykonania i stopień szczegółowości prezentowanych planów miast wiele mówi o poziomie kartografii wielkoskalowej w poszczególnych krajach. Panoramiczne przedstawienie topograficzne (il. 12) było zdecydowanie łatwiejsze do wykonania niż rzut izometryczny (il. 10, 11 i 13). Poświadcza to monumentalna praca

${ }^{62} \mathrm{~W}$ momencie pisania dzieła znane były dwa tomy Civitates orbis terrarum, były one opublikowane w latach 1572-1575.

${ }^{63}$ S. Sarnicki, Księgi hetmańskie, s. 137; por. A. Bartoszewicz, H. Bartoszewicz, Dzieje kartografi miast polskich do końca XIX wieku. Zarys problematyki, „Polski Przegląd Kartograficzny” 45 (2013), nr 3, s. 237; J. Łuczyński, Miasta Rzeczypospolitej na planach $i$ widokach $w$ Civitates orbis terrarum Georga Brauna i Franza Hogenberga (rozważania nad treścia ikonograficzna), w: Dawna kartografia miast, red. J. Ostrowski, P.E. Weszpiński, Warszawa 2011, s. 59-83.

${ }^{64}$ Ujęcie panoramiczne przedstawia również Widok Grodna wykonany w 1567 roku przez Hansa Adelhausera i rok później wydany jako grafika. M. Gębarowicz, Poczatki malarstwa..., s. 23-24 oraz il. 22-25. 


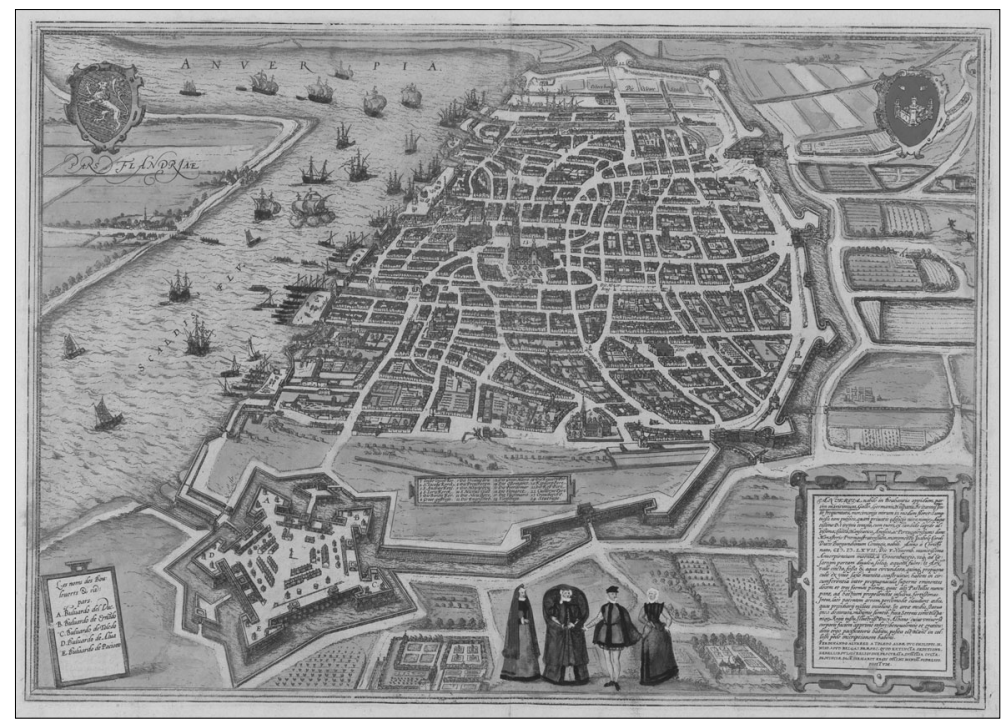

Il. 11. Plan Antwerpii opublikowany w pracy Georga Brauna i Fransa Hogenberga Civitates orbis terrarumn (G. Braun, F. Hogenberg, Civitates orbis terrarum, vol. I, Köln: Theodor Graminaeus, 1572, k. 17, https://www.metmuseum.org/art/collection/search/366878, dostęp: 11.12.2017)

Hartmanna Schedla wydana w 1493 roku, w której zaprezentowano jedynie panoramy miast, przy czym niektóre ukazane są z perspektywy wzniesienia. Przykładem takiego przedstawienia jest plan Krakowa, Kazimierza i Kleparza, stanowiący krok w procesie zmierzającym do ukazania rzutu ukośnego (il. 12) ${ }^{65}$. Analiza tego dzieła i jego wiarygodność wykracza poza ramy niniejszej pracy, trzeba jednak

${ }^{65} \mathrm{H}$. Schedel, Registrum huius operis libri cronicarum cum figuris et imagibus ab inicio mundi, Nürnberg: Anthonius Koberger, 1493, Bayerische Staatsbibliothek, Rar 287, k. 269v.-270 (wizerunek Krakowa). Autorem rozdziału dotyczącego Sarmacji, a być może także podstawy źródłowej do drzeworytu, był przebywający od 1489 do 1491 roku w Krakowie Konrad Celtis. T. Sinko, Celtis Konrad, w: Polski słownik biograficzny, t. 3, Kraków 1937, s. 266-267. 


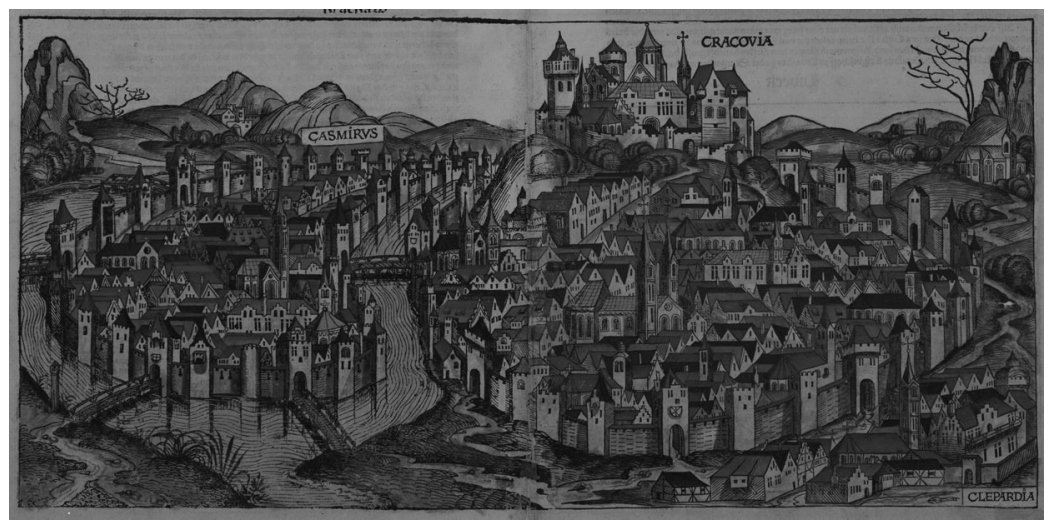

Il. 12. Plan Krakowa, Kazimierza i Kleparza, 1493 (Muzeum Historyczne Miasta Krakowa, sygn. 1591/VIII, drzeworyt z kręgu Michaela Wolgemuta i Wilhelma Pleydenwurffa prawdopodobnie według rysunku Konrada Celtisa, http://muzea.malopolska.pl/obiekty/-/a/26855/1124880, dostęp: 7.12.2017)

odnotować, że forma odwzorowania pozwalała już na stosunkowo precyzyjną ocenę stanu fortyfikacji około połowy powierzchni założenia. Na ilustracji przedstawiono wieże, bramy, główne budynki, sieć rzeczną i drożną, a także inne elementy topograficzne od strony północno-wschodniej ${ }^{66}$.

${ }^{66}$ M. Marek, Drzeworyt „Widok Krakowa od pótnocy”, http://muzea.malopolska. pl/obiekty/-/a/26855/1124880 (dostęp: 7.12.2017). Autorka ocenia, że „teren ujęty jest nieco $z$ góry. Przedstawia schematyczny obraz zabudowy $w$ pewnym stopniu zgodnie z realiami Krakowa z końca XV wieku, uderza poprawnością topograficznej odpowiedniości. W szczegółach jednak nie odpowiada realiom, nie odtwarza rzeczywistego usytuowania i wyglądu budowli, a te, które można identyfikować, narysowane są bez znajomości ich cech charakterystycznych, dlatego można mówić o przedstawieniu półportretowym, półfantastycznym". 
Tworzenie izometrycznych widoków miast spopularyzował Sebastian Münster, który w 1544 roku wydał Kosmografię, a następnie wielokrotnie ją wznawiał i uzupełniał. Oddziaływanie tej pracy miało charakter dwutorowy. Po pierwsze, dzieło to ukazywało dorobek kartografii średnio- i wielkoskalowej. Po drugie, Münster zaangażował w pracę nad swym dziełem ponad stu kilkudziesięciu uczonych i możnych z całej Europy. Pisał do nich, prosząc o dostarczenie opisu krajów i miast oraz wykonanie map i planów, a także o przesłanie gotówki potrzebnej na ich druk. W listach popularyzował nowe rozwiązania, zachęcał do podjęcia wysiłków kartograficznych. W połowie XVI stulecia, przygotowując trzecie wydanie Kosmografii, Münster chciał poszerzyć swoje dzieło o dodatkowe wiadomości pochodzące z Pol$\mathrm{ski}^{67}$. Przede wszystkim prosił o wykonanie rysunków miast - imiennie wskazywał na dawną i obecną stolicę - Gniezno i Kraków. W tej sprawie pisał między innymi do Zygmunta I Starego, Andrzeja Górki, Jana Tarnowskiego i Stanisława Łaskiego ${ }^{68}$. Jeszcze ważniejsza od samej prośby jest informacja o formie dzieła. Jak zauważa Jasper van Putten, Münster w liście do Łaskiego akcentuje potrzebę wykonania planu Krakowa i okolic z perspektywy izometrycznej, właściwie zbliżonej do rzutu dwuwymiarowego, na podobieństwo Paryża (il. 13) ${ }^{69}$ :

Należy aby tak duże miasto, składające się z trzech odrębnych gmin ujęte było we właściwej wielkości z uwydatnionemi jednak obwarowaniami, rzeką, mostem, zamkiem, Kolegium i ważniejszemi kościołami, podobnie jak i ja bardzo wielkie miasto Lutecji [Paryż - K.Ł.] ze wszystkiemi znaczniejszemi budynkami pomieściłem na małym formacie ${ }^{70}$.

${ }^{67}$ M. McLean, The Cosmographia of Sebastian Münster. Describing the World in the Reformation, Aldershot 2007, passim (w szczególności s. 149-150, 157, 181, 208-209, 225-226, 235-236).

68 W.A. Konczyńska, List Sebastiana Münstera do Stanisława Łaskiego i garść szczegółów w związku z jego „Kosmografja”, Kraków 1936, s. 4-6, 13-16; S. Münster do S. Łaskiego, Bazylea 6 IV 1548, w: ibidem, s. 8-10.

${ }^{69}$ J. van Putten, Networked Nation. Mapping German Cities in Sebastian Münster's 'Cosmographia', Leiden-Boston 2017, s. 81-85. Za zwrócenie uwagi na tę książkę serdecznie dziękuję prof. Jakubowi Niedźwiedziowi.

70 S. Münster do S. Łaskiego, Bazylea 6 IV 1548, s. 9. 


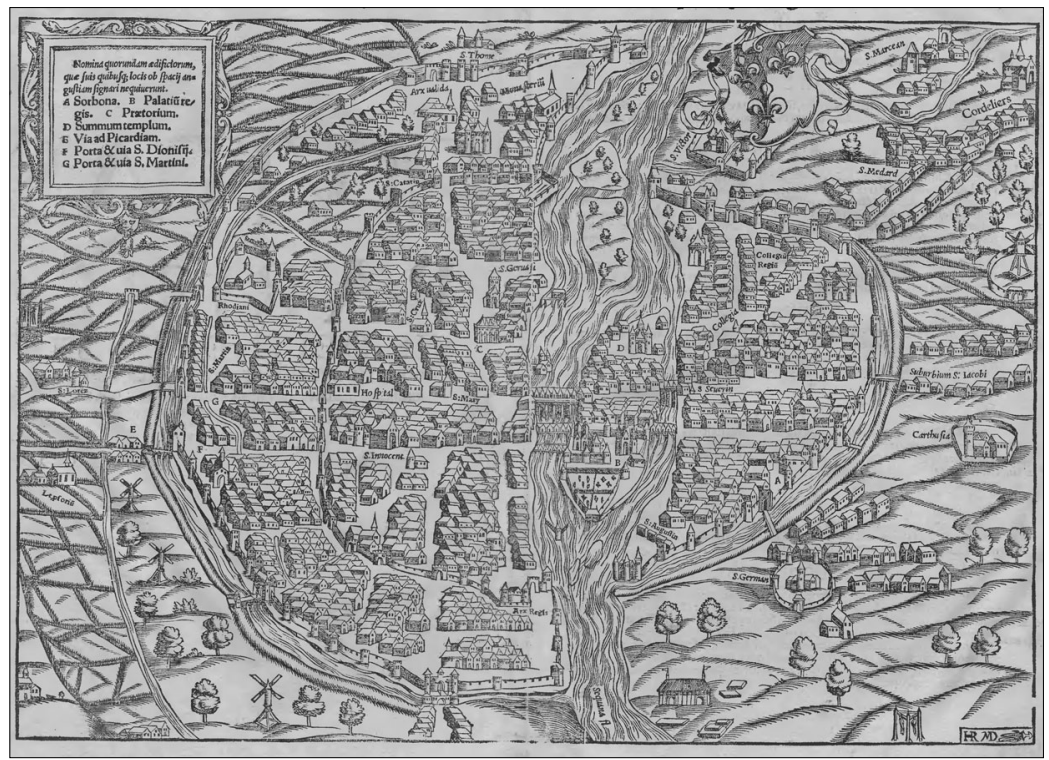

Il. 13. Hans Rudolf Manuel Deutsch, plan Paryża (S. Münster, Cosmographia universalis, Basileae: Heinrich Petri, 1550, s. 88-89, https://www.dbc. wroc.pl/dlibra/publication/10646/edition/9548/content?ref=desc, dostęp: 7.12.2017)

W kolejnych wydaniach Kosmografii brak nowych dzieł z terenu Korony, co może świadczyć o tym, że takowe nie powstały, a tym samym stanowiłoby to dowód na niewielki potencjał kartograficzny we władztwie Jagiellonów ${ }^{71}$. Niewątpliwie jednak korespondencja zawierająca takie prośby tworzyła świadomość przemian zachodzących w Europie i zapóźnienia występującego na ziemiach Rzeczypospolitej.

${ }^{71}$ S. Münster, Cosmographia universalis, Basileae: Heinrich Petri, 1550, s. 885913 (egzemplarz: Zakład Narodowy im. Ossolińskich, sygn. XVI.F.4280). 
Niewykluczone również, że z inicjatywą Sebastiana Münstera wiąże się powstanie pierwszego zachowanego izometrycznego rzutu miasta położonego na terenie Rzeczypospolitej. Chodzi o plan Wilna, który został umieszczony w trzecim tomie Civitates orbis terrarum z roku 1581 (il. 14) ${ }^{72}$. Jest on bardzo precyzyjny, zawiera wszystkie ważne punkty topograficzne i obiekty miejskie. Mimo występujących zniekształceń źródło to stanowi ważny krok w procesie przechodzenia od panoramicznych wizerunków miast i zamków do map wielkoskalowych. Okoliczności powstania planu wciąż pozostają niewyjaśnione - Michał Homolicki i Jan Fijałek utrzymują, że powstał on około $1550 \mathrm{roku}^{73}$. Jest to interesująca hipoteza, brak jednak na to dostatecznych dowodów ${ }^{74}$.

Biorąc pod uwagę spostrzeżenie Sarnickiego o wykorzystaniu przez najeźdźców wydanych drukiem planów miast, publikacja przedstawienia fortyfikacji wileńskich była nierozważnym posunięciem. Ukazuje ona fatalny stan przygotowania stolicy Wielkiego Księstwa Litewskiego na ewentualne oblężenie.

72 Zamek Królewski w Warszawie, Muzeum, Kolekcja dr. Tomasza Niewodniczańskiego, sygn. TN 5346 (dep. Deutsch-Polnische Stiftung Kulturpflege und Denkmalschutz).

${ }^{73}$ M. Homolicki, O planach Wilna, jakiem było w XVI wieku, „Wizerunki i Roztrząsania Naukowe. Poczet Nowy Drugi" 24 (1843), s. 2-6; J. Fijałek, Opisy Wilna aż do połowy XVII wieku, „Ateneum Wileńskie” 1 (1923), s. 320-321.

${ }^{74}$ Najpoważniejszy argument to użycie pod numerem 3. nazwy własnej: „Die jong. Königinne haus", co należy utożsamić z pałacem Barbary Radziwiłłówny. M. Homolicki, O planach Wilna..., s. 5. Dużego wyboru potencjalnych twórców planu Wilna z okresu panowania Zygmunta nie ma. Osobą, która mogłaby wykonać takie dzieło, był przyjęty w 1548 roku na dwór Zygmunta Augusta w Wilnie Antonio Mora. Hiszpan ten został królewskim inżynierem. Inna możliwość to uznanie za twórcę architekta królewskiego Joba Praytfuessa, który w 1551 roku został mianowany przełożonym budowli wileńskich (po śmierci Fryderyka Unscherfta) i awansował w 1559 roku na horodniczego wileńskiego. M. Ferenc, Dwór Zygmunta Augusta. Organizacja i ludzie, Oświęcim 2014, s. 99; J. Maroszek, Pogranicze Litwy i Korony w planach króla Zygmunta Augusta. Z historii dziejów realizacji myśli monarszej między Niemnem a Narwia, Białystok 2000, s. 311-312. 


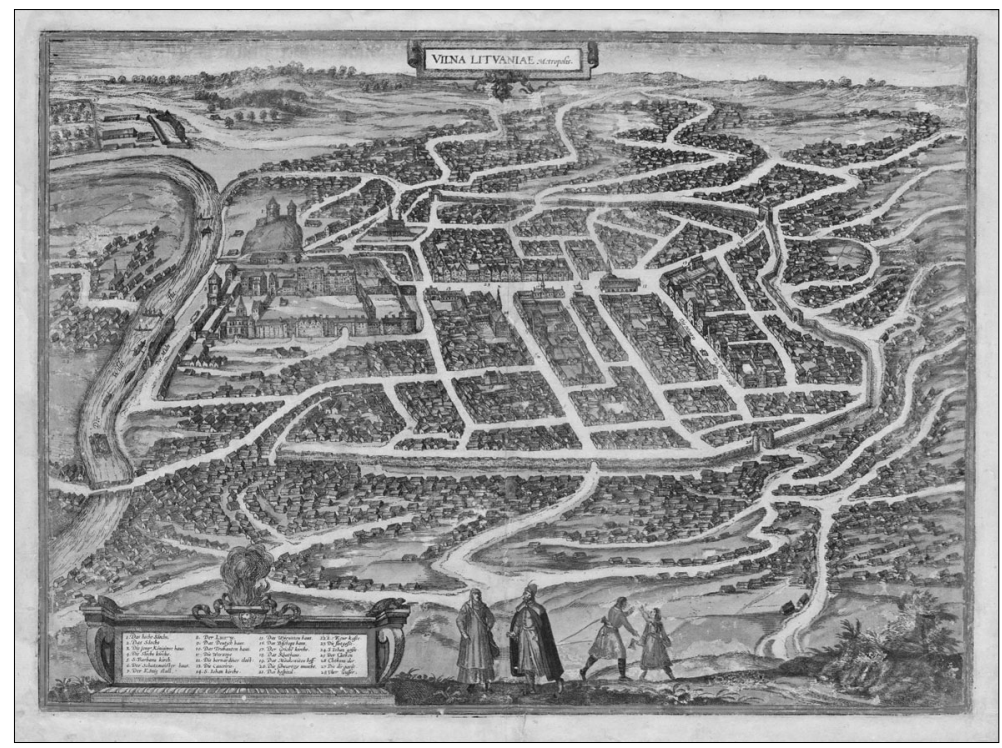

Il. 14. Plan Wilna (G. Braun, F. Hogenberg, Civitates orbis terrarum, vol. I, Köln: Theodor Graminaeus, 1572, http://elibrary.mab.lt/bitstream/handle/1/2053/268048.pdf? sequence $=1$ \&isAllowed $=y$, dostęp: 11.01.2017) ${ }^{75}$

Najstarsze poświadczone przypadki wykorzystania planów umocnień na potrzeby działań ofensywnych pochodzą z roku 1568. Wówczas armia Wielkiego Księstwa Litewskiego dwukrotnie oblegała twierdzę Ułę ${ }^{76}$. Pierwsza wyprawa spod Radoszkowic dowodzona przez Jana Hieronimowicza Chodkiewicza zakończyła się niepowodzeniem po trzytygodniowym oblężeniu. $\mathrm{Z}$ początkowego okresu

${ }^{75}$ Opis dołączony do mapy opublikowanej w Civitates orbis terrarum: Teksty opisowe Wilna, oprac. J. Fijałek, „Ateneum Wileńskie” 1 (1923), s. 516-521.

${ }^{76}$ S. Alexandrowicz, K. Buczek, Polska kartografia wojskowa do połowy XVII wieku, w: Dzieje polskiej kartografii wojskowej i myśli strategicznej, materiały z konferencji, oprac. B. Krassowski, J. Madej, Warszawa 1982, s. 11-13; S. Alexandrowicz, Rozwój kartografii..., s. 184-191. 


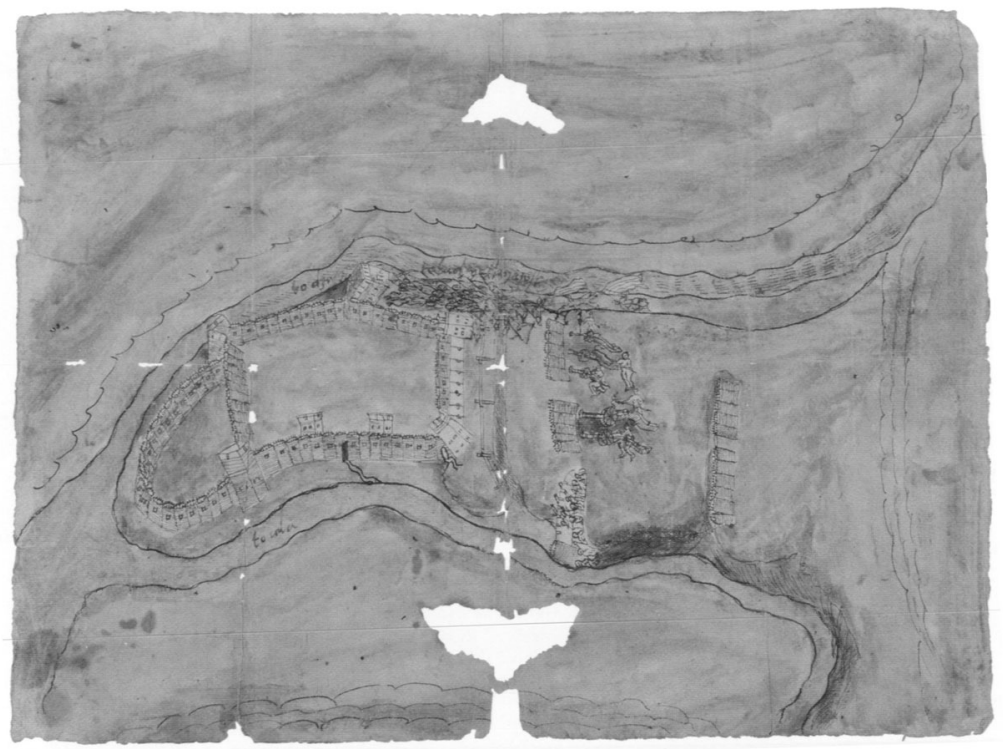

Il. 15. Plan fortyfikacji i działań oblężniczych pod Ułą w 1568 roku (Archiwum Narodowe w Krakowie, Archiwum Sanguszków, Teki Rzymskie Sanguszków, teka XI/78, k. 1)

oblężenia (12-15 lutego 1568 r.) pochodzi zachowany rękopiśmienny plan fortyfikacji zamku wraz z zaznaczonymi działaniami oblężniczymi oraz wycieczką załogi moskiewskiej, która zagarnęła litewskie działa (il. 15) ${ }^{77}$. Źródło to dokumentuje stan fortyfikacji, ale jednocześnie prezentujące działania wojenne prowadzone przy twierdzy.

77 Archiwum Narodowe w Krakowie, Archiwum Sanguszków, Teki Rzymskie Sanguszków, teka XI/78, k. 1; S. Alexandrowicz, Plan oblężenia zamku Uły z 1568 roku (przyczynek do poczatków staropolskiej kartografii wojskowej), „Polski Przegląd Kartograficzny" 18 (1986), nr 4, s. 165-175; idem, Kartografia Wielkiego Księstwa Litewskiego..., s. 164-166. 
Krój pisma znajdującego się na planie potwierdza hipotezę, że twórcą tego źródła był Maciej Stryjkowski ${ }^{78}$. Wspomniany żołnierz opisywał umiejętności właściwe inżynierowi wojskowemu:

[...] do rysowania sztuk zwłaszcza do matematyki, geografijej i perspektywy należących, które ćwiczenie nie mniej mi pomogło do przedsięwziętej peregrynacyjej i opisowania miast i zamków liflandzkich, moskiewskich etc. i inszych, którem zwiedził, krainy ${ }^{79}$.

Fragment ten w zestawieniu z planem Uły wskazuje, że podobnych źródeł kartograficznych było dużo więcej.

Szczególnie interesująca jest druga wyprawa pod Ułę, tym razem dowodzona przez księcia Romana Sanguszkę, z sierpnia 1568 roku $^{80}$. Sanguszko stacjonował wówczas w Czaśnikach z armią liczącą 1150 jazdy i 550 piechoty ${ }^{81}$. Przy pomocy szpiegów prowadzono stałą obserwację Uły, a wódz miał plan twierdzy (il. 15, być może przekazał go Maciej Stryjkowski). Po pojawieniu się informacji o przybyciu nowej załogi luzującej oddziały moskiewskie w zamku Uła Sanguszko podjął decyzję o ataku. Odległość Czaśnik od Uły w linii prostej wynosiła aż $42 \mathrm{~km}^{82}$. Przebycie tej odległości w jeden dzień było

${ }^{78}$ M. Plewczyński, Kozacy $w$ walkach $z$ Moskwa nad Dźwina $i$ Uła w latach 1567-1568, w: Od Kijowa do Rzymu. Z dziejów stosunków Rzeczypospolitej ze Stolica Apostolska i Ukraina, red. M.R. Drozdowski, W. Walczak, K. Wiszowata-Walczak, Białystok 2012, s. 66.

${ }^{79}$ M. Stryjkowski, Kronika polska..., k. A iij v.

${ }^{80}$ Szczegółowy opis kampanii: S. Alexandrowicz, Kartografia Wielkiego Księstwa Litewskiego..., s. 163-168; M. Plewczyński, Kozacy w walkach..., s. 67-70.

${ }^{81}$ Zygmunt August do R. Sanguszki, Knyszyn 21 VII 1568, w: Archiwum XX. Sanguszków w Sławucie, t. 7: 1554-1572 (dyplomataryusz gałęzi Niesuchojeżskiej. T. 2), Lwów 1910, s. 279.

82 Do analizy działań wojennych prowadzonych w sierpniu 1568 roku bardzo przydatna jest mapa Stanisława Pachołowieckiego, która mimo że wykonana 10 lat później prezentuje niewiele zmienioną siatkę osad i fortyfikacji. Uwzględnienie różnic jest możliwe dzięki pracy: G. Franczak, Filologia mapy. Badanie dawnej kartografi metoda krytyki tekstu na przykładzie toponimii mapy Księstwa Połockiego S. Pachołowieckiego z 1580 roku, „Terminus” 19 (2017), z. 1 (42), s. 193-252. 
możliwe, ale wymagało ogromnego wysiłku ${ }^{83}$. Jeszcze w Czaśnikach zwołano naradę wojenną, podczas której Sanguszko, wykorzystując materiał kartograficzny, „zamek im ów narysowawszy jako stał, [wskazał dowódcom - K.Ł.] gdzie który przystąpić miał"84. Został wówczas sporządzony plan zamku na bazie archetypu wykonanego zimą podczas pierwszego oblężenia Uły. Bartosz Paprocki pisze o rozdzieleniu zadań z wykorzystaniem rozrysowanego planu działania ${ }^{85}$. Były one następujące:

a) Kozacy Minka mieli podpalić zamek u ujścia rzeki Uły do Dźwiny;

b) Kozacy Biruli mieli zniszczyć częstokół, a następnie wrota;

c) Kozacy Mikity i Oskierki zobowiązani zostali do obrony bram zamkowych, by blokować tym samym możliwość kontruderzenia;

d) Piechota Rączkowskiego i Tarnowskiego miała podjąć szturm (brak danych o miejscu ataku);

e) W momencie podpalenia zamku odwód jazdy miał ruszyć przez rzekę Ułę i wspomóc walczących.

Roman Sanguszko popisał się przy tym wysokimi zdolnościami operacyjnymi. Wydzielił bowiem dwa pułki. Pierwszy, kozacki, wzmocniony rotami pieszymi Jerzego Rączkowskiego i Sebastiana Tarnowskiego, miał przebyć drogę łodziami z prądem rzeki Uły z Czaśnik aż do jej ujścia do Dźwiny. Pułk drugi - litewski złożony

83 Ogromne armie Stefana Batorego przemieszczały się w tempie $14 \mathrm{~km}$ dziennie, siły Krzysztofa Radziwiłła „Pioruna” w wyprawie pod Kierepeć w 1579 roku miały średnie tempo marszu równe $21,5 \mathrm{~km}$ dziennie. W obu przypadkach poruszano się $\mathrm{z}$ taborem. M. Wrede, Itinerarium króla Stefana Batorego 1576-1586, Warszawa 2010, s. 42; K. Łopatecki, Wyprawa zbrojna Krzysztofa Radziwiłła „Pioruna” w Inflantach zima 1579 roku, „Zapiski Historyczne” 83 (2018), z. 1, s. 53, 61.

84 B. Paprocki, Herby rycerstwa polskiego, wyd. K.J. Turowski, Kraków 1858, s. 831; cytat ten wykorzystują między innymi S. Alexandrowicz, K. Buczek, Polska kartografia wojskowa..., s. 11-12; M. Plewczyński, Kozacy w walkach..., s. 67.

${ }^{85}$ B. Paprocki, Herby rycerstwa..., s. 830-831; por. M. Stryjkowski, Kronika polska..., s. 774 . 
był z jazdy i powinien posuwać się wzdłuż lewego brzegu rzeki. Ta formacja miała stacjonować na drodze prowadzącej z Połocka i Turowli do Uły, a jej zadanie polegało na powstrzymaniu ewentualnej odsieczy moskiewskiej, stanowiła również odwód, najważniejsze zaś zadania powierzono flocie rzecznej.

W zasadzie założenia taktyczne zostały w pełni zrealizowane nie znano jedynie miejsc położenia brodów na Ule, ale przypadkowo wybrane miejsce okazało się dla armii litewskiej szczęśliwe ${ }^{86}$. Zdobycie zamku późną nocą z 20 na 21 sierpnia 1568 roku wiązało się niestety z jego spaleniem i całkowitym zniszczeniem.

Relacje Paprockiego i Stryjkowskiego dotyczące zdobycia zamku stanowią jedno z najwcześniejszych źródeł europejskich potwierdzających praktyczne wykorzystanie wiedzy kartograficznej podczas działań taktycznych ${ }^{87}$. Porównywalnym wydarzeniem na zachodzie Europy, przy zachowaniu wszelkich proporcji, było oblężenie Sieny w latach 1553-1555. Wówczas książę Kosma I Medyceusz planował działania oblężnicze, wykorzystując mapy ${ }^{88}$. Spotkało się to z krytyką ze strony wybitnego kondotiera i dowódcy, Medeghina (Gian Giacomo Medici $)^{89}$. Niemniej jednak sukces zapewnił Medyceuszowi sławę w Europie, a Giorgio Vasari namalował nawet obraz (1563-1565), na którym ukazał księcia korzystającego z mapy wielkoskalowej podczas działań oblężniczych (il. 16).

${ }^{86}$ Por. T. Grabarczyk, „Sucha stopa” czy „skaczac w fale”. Przekraczanie rzek przez wojska polskie od XI do początku XVI wieku, „Acta Universitatis Lodziensis. Folia Historica" 99 (2017), s. 83-109.

${ }^{87}$ Zob. M. Pollak, Cities at War in Early Modern Europe, Cambridge 2010, s. $112-153$.

${ }^{88}$ J. Hale, Warfare and Cartography, ca. 1450 to ca. 1640, w: The History of Cartography, vol. 3: Cartography in the European Renaissance, part. 1, ed. D. Woodward, Chicago-London 2007, s. 723-724.

89 S. Pepper, N. Adams, Firearms \& Fortifications. Military Architecture and Siege Warfare in Sixteenth Century Siena, Chicago 1986, s. 126. 


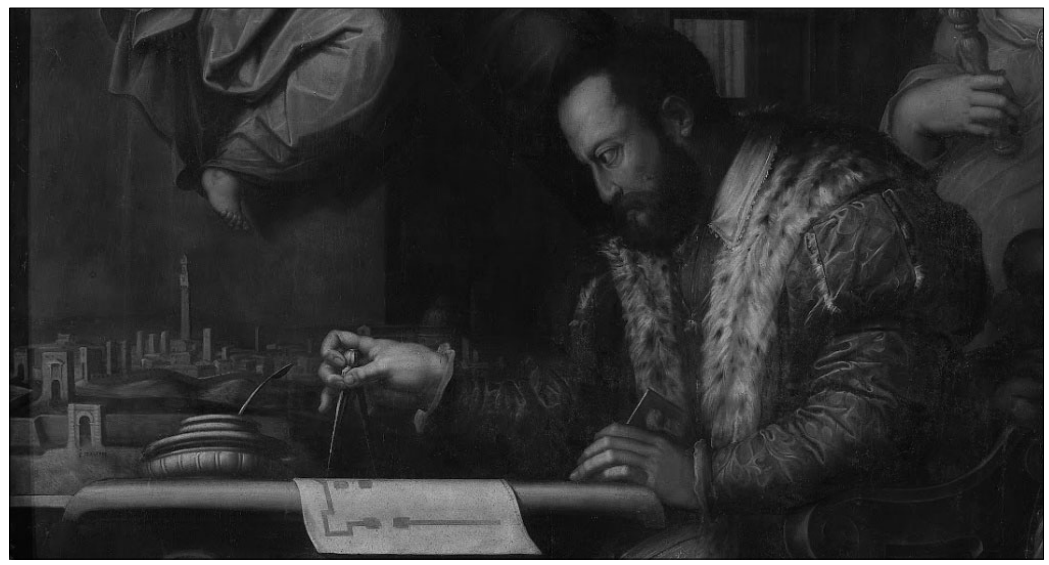

Il. 16. Giorgio Vasari, Kosma I Medyceusz planujący oblężenie Sieny (Florencja, Palazzo Vecchio, fragment)

W dotychczasowych badaniach akcentowano, że plan litewskiej Uły został wydany w odbitkach miedziorytniczych w 1570 roku, fortecy jednak nie wybudowano ${ }^{90}$. Warto to spostrzeżenie uzupełnić. Grafika przedstawiająca nową twierdzę Ułę jednocześnie informowała o sukcesie militarnym księcia Sanguszki, czyli o zdobyciu moskiewskiej twierdzy (il. 17). Sam tytuł druku jest znamienny: ULLA. Fortezza nel confin di Lattuania da nuovo presa per il Serenissimo Re di Polonia (Ułła. Twierdza na pograniczu Litwy, ponownie zdobyta przez najjaśniejszego króla Polski - przeł. Grzegorz Franczak) ${ }^{91}$. Do-

90 S. Alexandrowicz, Kartografia ziem Wielkiego Księstwa Litewskiego w epoce panowania Jagiellonów „Polski Przegląd Kartograficzny” 46 (2014), nr 1, s. 75; idem, Plan oblężenia zamku Uły..., s. 165-175.

91 Wymiary: 19,5 × 25,5 cm. Jeden $\mathrm{z}$ egzemplarzy był w posiadaniu Joachima Lelewela, następnie został przekazany do biblioteki uniwersyteckiej w Wilnie. M. Dzikowski, Zbiór kartograficzny Uniwersyteckiej Bibljoteki publicznej w Wilnie, Wilno 1932, s. 21, poz. 90. Egzemplarz ten jest przechowywany obecnie w Bibliotece Uniwersytetu Wileńskiego w kolekcji Joachima Lelewela, w zespole Atlasy, pod 
datkowo przy ujściu Uły do Dźwiny znalazł się napis: „Da questa parte passorno il fiume / con barche et attaccorno il foco / di modo che tutto abrusiorno" („Z tej strony przekroczyli rzekę łodziami i podłożyli ogień, od którego wszystko spłonęło" - przeł. Grzegorz Franczak). Adnotacja w pełni pokrywa się z informacją umieszczoną przez Paprockiego, w świetle której Sanguszko rotmistrzowi „Minkowi kazał z tyłu zamek zapalić" ${ }^{\prime 2}$. Jednocześnie plan Uły na grafice znacznie różni się od rysunku, co wskazuje na koncepcję budowy nowego zamku.

Należy zadać dwa powiązane ze sobą pytania. Po pierwsze: czy wykonywano plany pod planowaną budowę fortyfikacji? Po drugie: kto stworzył mapę litewskiej twierdzy Uła?

Dzisiaj, patrząc z naszej perspektywy, bezdyskusyjne przyjmuje się, że budowa czegokolwiek większego niż doraźne umocnienia polowe wymagała przygotowania planów (il. 3-6). Nie było to jednak dla współczesnych zupełnie oczywiste. Jeszcze Florian Zebrzydowski, pisząc w 1559 roku swoje Pouczenie dotyczące między innymi przebudowy istniejących fortyfikacji, zupełnie nie dostrzegał tego proble$\mathrm{mu}^{93}$. Z pewnością jednak od lat 60 . XVI wieku starano się precyzyjnie projektować założenia obronne. Taki projekt stworzono w 1567 roku na potrzeby budowy Blokhauzu (Bolwerku), czyli niewielkiej twierdzy położonej nad rzeką Dźwiną pomiędzy Rygą a Dźwinoujściem, której zadaniem było pobieranie cła od statków zmierzających do Rygi. Na przełomie czerwca i lipca Jan Chodkiewicz wysłał do króla kartografa Macieja Strubicza, który przekazał między innymi

tytułem Tabulae geographicae Jacobi Gastaldi Pedemontani cosmographi aliquot aliorum 1559-1570 [...]. Atlas ten został w całości zdigitalizowany i jest dostępny na stronie: http://www.atmintis.mb.vu.lt/kolekcijos/VUB01_000446259-00175 (dostęp: 10.12.2016).

${ }_{92}$ B. Paprocki, Herby rycerstwa..., s. 831.

${ }_{93}$ Porzadek żolnierski tak $w$ polu jako i na zamkach od P. Floriana Zebrzydowskiego opisany anno 1559, w: Hetman Florian Zebrzydowski o porządku wojennym, wyd. S. Bodniak, „Przegląd Historyczno-Wojskowy” 3 (1931), z. 2, s. 302-304. 
rysunek fortyfikacji ${ }^{94}$. Podobne działanie podjęto podczas budowy twierdzy u ujścia rzeki Dźwiny do morza - w samym porcie Dźwinoujściu ${ }^{95}$. Również budowa zamku tykocińskiego stanowiła przedmiot licznych debat, koncepcji i planów ${ }^{96}$. Prace rozpoczął w 1549 roku Job Praytfuess, pod koniec życia Zygmunta Augusta (począwszy od roku 1565) zaczęto budować bastionową twierdzę. W 1570 roku Zygmunt August przysłał Praytfuessowi widok (być może plan) twierdzy w Lubowli na Spiszu, gdzie w 1544 roku rozpoczęto budowę bastionu przy zamku ${ }^{97}$. Z tego samego czasu zachowały się informacje o dostarczeniu do Knyszyna i Tykocina kilku map, wśród nich między innymi „zamek jakiś na płótnie malowany”, a także „wizerunek miasta gdańskiego" ${ }^{\prime 8}$. W 1571 roku do króla przybył Wojciech Zakrzewski z planami twierdzy tykocińskiej ${ }^{99}$. Jeszcze dzień przed śmiercią - 6 lipca 1572 roku - Zygmunt August „,spytał mię [Łukasza Górnickiego - K.t.], jeślim z sobą przywiózł wizerunki [twierdzy tykocińskiej - K.t.]"100.

Współcześni korzystali nie tylko z rysunków i planów. Stanisław Sarnicki odnotował w Księgach hetmańskich, że założenia obronne można „z wosku [...] wyformować, aby hetman mógł łacniej wybaczyć, coby mu nieprzyjaciel mógł za zdradę uczynić i jako tego

${ }^{94}$ Zygmunt August do J. Chodkiewicza, 3 VII 1567, Biblioteka Książąt Czartoryskich w Krakowie, Teki Naruszewicza, sygn. 76, nr 45, s. 143-144; S. Bodniak, Polska a Battyk za ostatniego Jagiellona, „Pamiętnik Biblioteki Kórnickiej” 3 (1946), s. 270-271.

${ }^{9}$ Санкт-Петербургский институт истории РАН, f. 32, karton 694, nr 1, k. 190-190v.

${ }^{96}$ G. Chodkiewicz do R. Sanguszki, Zabłudów 19 IX 1568, w: Archiwum XX. Sanguszków..., s. 293.

${ }_{97}$ Księga ekspedycji kancelarii nadwornej 1559-1572. Materiały do dziejów dworu królewskiego, oprac. I. Kaniewska, Kraków 1997, s. 180; J. Maroszek, Pogranicze Litwy i Korony..., s. 313; M. Števík, Zamek w Lubowli na tle średniowiecznych dziejów pótnocnego Spiszu, „Rocznik Sądecki” 39 (2011), s. 48.

${ }^{98}$ Ksiega ekspedycji kancelarii..., s. 180.

99 J. Maroszek, Pogranicze Litwy i Korony..., s. 318-319.

100 Ł. Górnicki, Dzieje w Koronie Polskiej od r. 1538 do r. 1572, wyd. K.J. Turowski, Sanok 1855, s. 136. 
się uwiarować" 101 . Nie mamy tu do czynienia z zupełną aberracją, nie chodzi bowiem o wykonanie modeli w warunkach bojowych, lecz o przygotowanie makiet budowanych/zbudowanych obiektów. Skądinąd wiadomo, że ogromną wagę do trójwymiarowych makiet twierdz przykładali w XVI i XVII stuleciu Wenecjanie ${ }^{102}$. Zjawisko było dużo szersze - w 1550 roku Albrecht Hohenzollern sprowadził nawet makietę nowych fortyfikacji wykonanych w Ingolstadt. Podobnie uczynił Stefan Batory, kierując do twierdzy Wielkiego Waradynu (Gross-Wardein) inżyniera włoskiego Dominika Ridolfino. Otrzymał on instrukcję, zgodnie z którą miał w pierwszej kolejności rozeznać się w bezpośrednim otoczeniu twierdzy, następnie ocenić plany budowy wykonane przez poprzedniego, zmarłego już architekta. Na końcu instrukcji inżynier otrzymał polecenie: „rozglądnąwszy się należycie w twierdzy i obejrzawszy ją, nie mniej jej otoczenie, [...] powinien sporządzić jej model drewniany i jak najrychlej powrócić", oczywiście z wykonanym modelem twierdzy ${ }^{103}$.

Podsumowując powyższe rozważania - wydaje się, że pod koniec lat 60. XVI wieku plany stanowily już standardowy, wstępny etap prac fortyfikacyjnych. Zygmunt II August niezwłocznie po zdobyciu zamku Uła pisał do Romana Sanguszki o konieczności odbudowy. Władca nie zaaprobował propozycji księcia, aby w tym miejscu ulokować jedynie wieżę, którą obsadziliby Kozacy. Żądał odbudowy całego zamku, a do tego czasu osobistej obecności księcia, co zapobiegłoby dezercji. Król zapewnił, że napisze do podskarbiego Mikołaja Naruszewicza o potrzebie wyasygnowania pieniędzy oraz do okolicznych dzierżawców i starostów o udzielenie pomocy przy budowie fortyfikacji. Król gwarantował także dostarczenie artylerii

101 S. Sarnicki, Księgi hetmańskie, s. 259.

102 K. Barzmans, Cartographic Line and the "Paper Management" of the Early Modern State: A Case Study of Venetian Dalmatia, „Mapline” 122 (2014), s. 10-11 (przypis 9).

${ }^{103}$ K.Th., Dominik Ridolfino. Pułkownik w stużbie Rzplitej polskiej w XVI wieku, „Przewodnik Naukowy i Literacki” 15 (1887), s. 734. 
i wojsk zaciężnych ${ }^{104}$. Mimo tak dokładnych instrukcji władca i inni możni piszący do Romana Sanguszki nie wspominali nic o nowych planach fortyfikacji. Nie było na to czasu, nie było chyba też takiej potrzeby. Najpraktyczniejszym rozwiązaniem było wykorzystanie planów wykonanych kilka lat wcześniej (il. 17). W 1563 roku, już po upadku Połocka, Zygmunt August postanowił budować twierdzę u ujścia Uły do Dźwiny. Według Marka Plewczyńskiego twórcą fortyfikacji był Ambroży Gwagnin, zaciągnięty do służby wojskowej w 1561 roku wraz ze swym synem Aleksandrem. Prac na początku lat 60. XVI wieku nie udało się dokończyć, gdyż Rosjanie przegnali robotników i sami w późniejszym czasie podjęli prace fortyfikacyjne ${ }^{105}$. Ustalenia te potwierdza częściowo relacja Heidensteina, który stwierdził, że do budowy zamku Uła „włoskiego architekta tam sprowadził [król - K.Ł.], ale architekt zginął i nieprzyjaciel budowy nie dozwolił”106. Informacja o śmierci „włoskiego architekta” jest raczej bałamutna i niepotwierdzona w innych źródłach. Natomiast sam fakt zaplanowania założenia obronnego przez Włocha wydaje się przekonujący, tym bardziej gdy zestawimy tę informację z grafiką, na której umieszczono włoskie komentarze.

Sądzę, że autorem planów twierdzy z 1563 roku był Ambroży Gwagnin. Jego koncepcja posłużyła po raz kolejny w 1568 roku przy odbudowie umocnienia przez stronę litewską. Założenie zostało zrealizowane mimo dużych kłopotów z pozyskaniem środków pieniężnych i ludzi. Już 13 października 1568 roku Grzegorz Chodkiewicz dziękuje Romanowi Sanguszce za informacje o szybko po-

104 Zygmunt August do R. Sanguszki, Warszawa 5 IX 1568, w: Archiwum XX. Sanguszków..., s. 285-286.

105 M. Plewczyński, Włosi $w$ służbie koronnej za ostatnich Jagiellonów (15061572), „Studia i Materiały do Historii Wojskowości” 35 (1993), s. 306.

106 R. Heidenstein, Dzieje Polski od śmierci Zygmunta Augusta do roku 1594. Ksiag XII, t. 1, przeł. M. Gliszczyński, Petersburg 1857, s. 311. Obszar ten w świetle rewizji z 1552 roku należał do Semena Fedorowicza Ulskiego i siostry Fiedy Wasilewny Ulskiej, którzy posiadali tam ufortyfikowany dwór i wieś. Rewizja województwa połockiego z roku 1552, wyd. J. Szujski, w: Archiwum Komisyi Historycznej, t. 2, Kraków 1880, s. 234. 


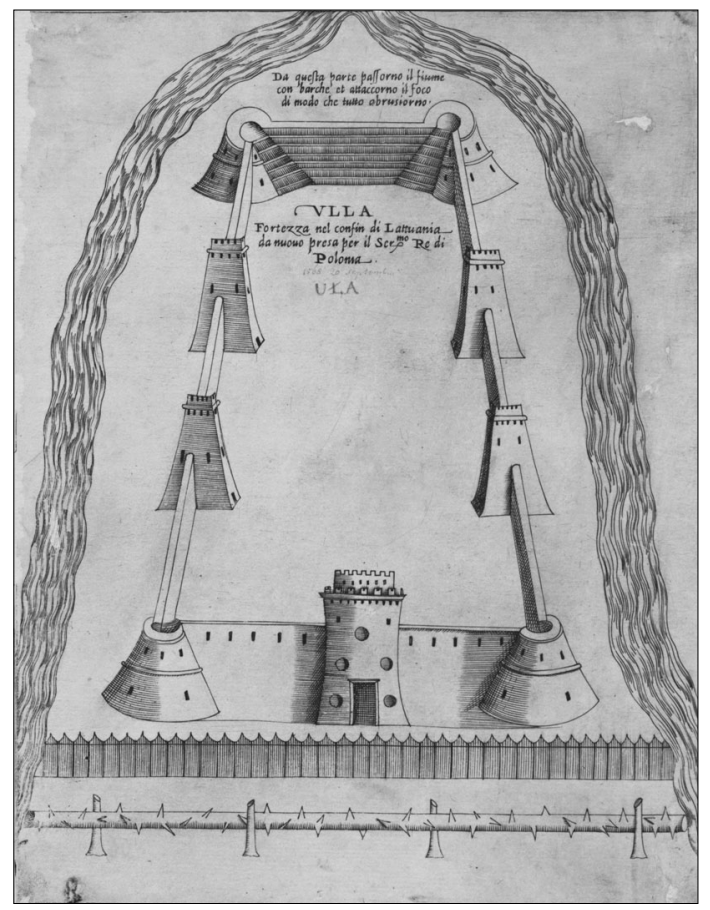

Il. 17. Twierdza Uła zbudowana przez wojska litewskie (Vilniaus Universiteto Biblioteka, J. Lelevelio fondas: Atlasai, Tabulae geographicae Jacobi Gastaldi Pedemontani cosmographi aliquot aliorum 1559-1570 [...], s. [181], http:// www.atmintis.mb.vu.lt/kolekcijos/VUB01_000446259, dostęp: 22.11.2017)

stępujących pracach budowlanych ${ }^{107}$. To, że podjęte działania były szczęśliwie zakończone, poświadczał w opublikowanej w roku 1578 Sarmatiae Europeae descriptio Aleksander Gwagnin. Potwierdzili to również Marcin Bielski oraz Maciej Stryjkowski ${ }^{108}$. W zamku tym

107 G. Chodkiewicz do R. Sanguszki, Piaski 13 X 1568, Archiwum XX. Sanguszków..., s. 298-299.

108 A. Gwagnin, Kronika Sarmacyjej Europskiej, Kraków: Mikołaj Lob, 1611, ks. III, s. 25-26: „od Moskwy niekiedy ten zamek był zbudowany i trzymany, nasi się 
stale stacjonowała załoga, w 1576 roku była to pięćdziesięcioosobowa rota kniazia Konstantego Łukomskiego ${ }^{109}$.

W kilku zdaniach warto porównać umocnienia moskiewskie z litewskimi ${ }^{110}$. W obu przypadkach naczelną zasadą było dostosowanie umocnień do warunków naturalnych, czyli wpasowanie twierdzy w ujście rzeki Uły do Dźwiny (il. 15 i 17). Koncepcja litewska była prostsza, Moskwa bowiem zbudowała zamek niejako z dwóch części - zasadniczej, dopasowanej do kształtu cypla (w formie lekko załamanego w połowie boku prostokąta), i dobudowanego do niej pozbawionego wież wału w samym ujściu rzeki. Przebieg zdobycia Uły ukazał, że ta „dobudówka” doprowadziła do upadku całego umocnienia. Pożar, który zajął drewniane fortyfikacje rozszerzył się bowiem na cały zamek. Inżynier włoski zaplanował bardziej zwarty kompleks o rzucie w kształcie trapezu równoramiennego. W konsekwencji wybudowano pięć bastei (cztery narożne i jedną $\mathrm{z}$ bramą wjazdową, tyle samo było ich w twierdzy rosyjskiej). Litewska konstrukcja miała więcej baszt - cztery, moskiewska zaś jedynie dwie chroniące bramę główną. Tym samym litewska konstrukcja zapewniała lepszą obronę przed szturmem. Dodatkowo wzmocniono stronę południową twierdzy, oprócz ostrokołu pobudowano również palisadę. W obu założeniach w cyplu pomiędzy rzekami, a przed twierdzą umieszczono kobyliny, palisady, być może rów, które dodatkowo miały zwiększyć walory obronne umocnienia. Główna różnica polegała na stworzeniu jednej tylko bramy ulokowanej w wieży umieszczonej w centralnej części dłuższej podstawy (południowej). Miało to związek z sytuacją geopolityczną. Brama południowa pro-

oń częstokroć kusili, ale próżno. Potem książę Koman Sanguszkowic, niespodziewanym szturmem ten zamek opanowawszy, spalił; i tamże go znowu naszy oprawiwszy, strzelbą i wszelakimi potrzebami wojennemi opatrzywszy, ludem wojennym osadzili”. Podobnie: Zbiór pisarzów polskich, cz. 6, t. 17: M. Bielski, Kronika Polska, [t. 7], Warszawa 1832, s. 175-176; M. Stryjkowski, Kronika polska..., s. 774.

${ }_{109}$ H. Kotarski, Wojsko polsko-litewskie podczas wojny inflanckiej 1576-1582, cz. 1, „Studia i Materiały do Historii Wojskowości” 16 (1970), z. 2, s. 110.

110 Por. S. Alexandrowicz, Kartografia Wielkiego Księstwa Litewskiego..., s. 168. 
wadziła bowiem bezpośrednio w kierunku Czaśnik, gdzie znajdował się główny punkt obrony armii litewskiej w okolicy. Rosjanie zaś musieli mieć połączenie z Turowlą, tym samym ulokowali główną bramę wjazdową na boku zachodnim, obok brodu znajdującego się na rzece Ule. Lokalizacja bramy od strony północno-wschodniej nie wchodziła w rachubę, Dźwiny w tym miejscu nie sposób było przekroczyć, tym samym nie istniało bezpośrednie połączenie z Połockiem.

O tym, jak powinna być budowana fortyfikacja, pisał w 1559 roku Florian Zebrzydowski do Mikołaja Radziwiłła. Po pierwsze, ukazywał potrzebę zastosowania „pobocznej strzelby” - czyli konieczności wysunięcia przed mur punktów umocnionych, które ochraniałyby kurtyny ostrzałem flankującym. W świetle planu twierdzy Uła - zostało to wykonane. Po drugie, Zebrzydowski wskazywał, że odległość kurtyn nie może być większa niż zasięg broni palnej. Rzeczywiście narożne basteje i cztery wieże ulokowane były w równych odległościach. Plan wskazuje, że naczelną zasadą budowniczego było pełne wykorzystanie ostrzału flankującego (nawet wieże były wysunięte przed lico muru i miały umieszczone z boku okna strzelnicze). Po trzecie, Zebrzydowski zwracał uwagę, że basteje mogą być budowane z drewna i gliny, lecz całą konstrukcję należało otynkować i pobielić (co mogło zmylić przeciwnika i zdecydowanie utrudniało jej podpalenie). Dodatkowo proponował wzmocnienie ziemią: ,a jeszczeby lepiej, kiedyby je w ziemi począł robić i ziemią je przykryć, aby z nich mogła być ziemna poboczna strzelba"111. Oczywiście litewska twierdza Uła była wykonana z drewna, ale jej wygląd na grafice wskazuje, że fortyfikacje zostały wykonane w taki sposób, jak proponował to Zebrzydowski ${ }^{112}$.

Niewątpliwie w dobie dynamicznego rozwoju artylerii umocnienia bastejowe nie były wystarczające. Na początku ofensywy na Wielkie Łuki w 1580 roku Stefan Batory przybył pod Ułę i Lepla, „zamków

111 Porządek żolnierski..., s. 303.

112 Ibidem; K. Łopatecki, Poglądy Floriana Zebrzydowskiego dotyczące ufortyfikowania, obrony i poddania twierdz, „Białostockie Teki Historyczne” 13 (2015), s. 96-98. 
pobliższych, dla rozpoznania na miejscu, czyli oszańcowane, czyli zburzone być miały"113. Ówczesny inżynier na służbie króla - Dominik Rudolfino - 26 lipca 1580 roku pisał w liście z Witebska: „Sześć dni temu powoływano mię do króla Jegomości, abym oglądał projektowane plany dwu twierdz. Stanęło na mojem, iż nie należy ich obwarowywać w proponowany sposób, ponieważ niestosowny"114. Tym samym nie został zrealizowany plan (nieznany) rozbudowy zamku Uła.

Nowatorskie koncepcje, wiedzę, umiejętności przynosili do kraju obcokrajowcy. W zasadzie do lat 70. XVI wieku w kartografii przodowali włoscy inżynierowie wojskowi ${ }^{115}$. Tacy jednak omijali ziemie koronne i litewskie ${ }^{116}$. W 1548 roku na dworze Zygmunta Augusta pojawił się Hiszpan tytułowany inżynierem wojskowym - Antonio Mora. Rezultaty jego działań każą wątpić, czy miał on wysokie kwalifikacje zawodowe ${ }^{117}$. Od 1561 roku do armii koronnej zostali zwerbowani pochodzący z Werony (Rzeczpospolita Wenecka) Gwagninowie, ojciec - Ambroży i syn - Aleksander. Ich umiejętności stały na dobrym poziomie, w szczególności ojciec był oceniany jako specjalista od budowy mostów i umocnień. Niewątpliwie zasługą Gwagninów było ufortyfikowanie i utrzymanie w latach 60. i 70. XVI stulecia Witebska $^{118}$. Sądzę, że pod ich okiem kształciło się kolejne pokolenie

113 J.Ch. Albertrandy, Panowanie Henryka Walezyusza i Stefana Batorego krolów Polskich, wyd. Z. Onacewicz, Kraków 1860, s. 155; K. Olejnik, Stefan Batory 1533-1586, Warszawa 1988, s. 184. Por. R. Heidenstein, De Bello Moscovitico commentariorum libri sex, Kraków: Drukarnia Łazarzowa, 1584, s. 100.

${ }_{114}$ K.Th., Dominik Ridolfino..., s. 653.

115 D. Parrott, The Utility of Fortifications in Early Modern Europe..., s. 127-153 (szczególnie: 148-152).

116 M. Plewczyński, Włosi w służbie koronnej..., s. 301-309. Odmiennie: H. Kotarski, Wojsko polsko-litewskie..., cz. 1, s. 102.

117 Antonio Mora pełnił funkcję królewskiego inżyniera wojskowego od 16 lutego 1548 roku do około 1562 roku, w późniejszym okresie łączył ją z obowiązkami rotmistrza. J. Jasnowski, Antoni Mora. Hiszpan w stużbie Zygmunta Augusta, „Przegląd Historyczno-Wojskowy" 9 (1936), z. 2, s. 305-306; M. Ferenc, Dwór Zygmunta Augusta..., s. 99.

${ }^{118}$ M. Plewczyński, Włosi w służbie koronnej..., s. 305-306. 
specjalistów. Taką osobą, która zaczęła wykonywać mapy i plany, był Maciej Stryjkowski, służący jako towarzysz w wojsku litewskim od połowy lat 60. XVI wieku aż do lat 1572-1573, kiedy to był towarzyszem na zamku witebskim ${ }^{119}$. W tym okresie, jak sam pisał:

[...] dowcip mój do trudnych rzeczy przeważny i natura do widzenia rozmaitych krain chciwa ku temu mię przywiodły, iż przez niektóry czas mając ku temu przyrodzone ingenium, przewykłem i do rysowania sztuk, zwłaszcza do matematyki, geografijej i perspektywy należących ${ }^{120}$.

Zatarg pomiędzy Aleksandrem Gwagninem a Maciejem Stryjkowskim o rzekomy plagiat lub też kradzież pracy przez Włocha jest $\mathrm{w}$ literaturze dobrze znany. Stryjkowski raczej więc nie miał powodów dziękować werończykom za otrzymaną naukę.

Swoje kompetencje Maciej Stryjkowski rozwijał po zakończeniu służby wojskowej. W latach 1574-1575 udał się do Turcji jako poseł wraz z podczaszym halickim Andrzejem Taranowskim ${ }^{121}$. Opisując swoją podróż po Porcie Otomańskiej, podkreślał, że posiadał wówczas doświadczenie kartograficzne i malarskie, dzięki czemu mógł uzyskać dodatkowy zarobek.

Jam zaś miał pewną żywność w swym z młodu ćwiczeniu,

Bo świat zwiedzić chęć mając (a iż skarb, klejnoty

Złodziej kradnie, krom nauk świętych, rzemiosł, cnoty),

Nawykłem był rysować figur z przyrodzenia,

Iluminując złotem, farbą jak z ćwiczenia ${ }^{122}$.

119 J. Radziszewska, Maciej Stryjkowski. Historyk-poeta z epoki Odrodzenia, Katowice 1978, s. 19, 31 i nn.; Z. Wojtkowiak, Maciej Stryjkowski..., s. 58-59.

${ }^{120}$ M. Stryjkowski, Kronika polska..., k. A iijv; por. S. Alexandrowicz, Rozwój kartografii..., s. 191; J. Kowalczyk, Sebastiano Serlio a sztuka polska. O roli włoskich traktatów architektonicznych $w$ dobie nowożytnej, Wrocław 1973, s. 15; J. Radziszewska, Maciej Stryjkowski..., s. 20.

${ }^{121}$ J. Radziszewska, Ze studiów nad turecką misją Macieja Stryjkowskiego, „Rocznik Biblioteki Naukowej PAU i PAN w Krakowie” 48 (2003), s. 31-55.

${ }_{122}$ M. Stryjkowski, Kronika polska..., k. XX iijr. (Maciej Stryjkowski Osostevicius sam o sobie i przygodach swoich $w$ zwiedzeniu rozmaitych krain świata). 
Uważam, że pierwszym inżynierem wojskowym reprezentującym najwyższy poziom europejski, który znalazł się na służbie polsko-litewskiej, był Dominik Ridolfino. Został on sprowadzony do Rzeczypospolitej w związku z wyprawą pod Wielkie Łuki w 1580 roku $^{123}$. Trzy wyprawy na państwo moskiewskie i poprzedzający ją konflikt z Gdańskiem to rzeczywiście czas przełomowy, który wymaga odrębnych badań.

\section{Podsumowanie}

1. Pierwszym teoretykiem, który powiązał działalność kartograficzną z taktyką wojskową, był Szymon Marycjusz z Pilzna. Tezy swoje przedstawił w wydrukowanej w 1551 roku pracy De scholis seu academiis libri duo. Zebrane dowody wskazują, że w pierwszej połowie XVI wieku nie potrafiono wykorzystać kartografii na potrzeby taktycznych działań wojennych.

2. Wojskowa kartografia wielkoskalowa miała odmienne podstawy metodologiczne niż mapy średnio- i małoskalowe. Podstawowe założenie metodologiczne przy tworzeniu planów polegało na odejściu od maniery malarskiej (pejzażowych przekazów topograficznych - il. 1 i 12) na rzecz obejścia rozrysowanego terenu dookoła (il. 11, 13 i 14). Postulował to już Stanisław Grzepski, powołując się na Albrechta Dürera, a opisy takiego działania pochodzą z przekazów Macieja Stryjkowskiego z połowy lat 70. XVI wieku. Taką praktykę działania poświadcza również plan fortyfikacji Uły wykonany w 1568 roku (il. 15).

123 K.Th., Dominik Ridolfino..., s. 645-658; H. Kotarski, Wojsko polsko-litewskie podczas wojny inflanckiej 1576-1582, cz. 3, „Studia i Materiały do Historii Wojskowości” 17 (1971), z. 2, s. 89-90. 
3. Precyzja wykonania wojskowych map wielkoskalowych wymagała wykorzystania wiedzy matematycznej, geometrycznej. Pojawiła się potrzeba powołania specjalnej grupy zawodowej, która między innymi mierzyłaby wysokość, szerokość i głębokość obiektów. Wykorzystanie matematyki w wojsku postulował już w 1555 roku Albrecht Hohenzollern, a grupę zawodową inżynierów wojskowych (nazywając ich metatores castrorum) opisał po raz pierwszy Stanisław Sarnicki w Księgach hetmańskich. Inżynierowie wojskowi powinni posługiwać się prętem i sznurem mierniczym, kompasem (busolą), laską Jakubową, ewentualnie kwadrantem i astrolabium (il. 2-6).

4. Kartografia wielkoskalowa przydatna była do zataczania i lokowania obozów wojskowych (Jan Tarnowski i Albrecht Hohenzollern), ustalania ordre de bataille (Albrecht Hohenzollern, Marcin Bielski i Stanisław Sarnicki - il. 7a, 7b, 8 i 9), a także planowania nowych założeń obronnych (Tykocin, Gdańsk, Dźwinoujście, Blokhauz, Lubowla, Uła - il. 17). Przy pracach budowlanych powstawały nawet trójwymiarowe makiety założeń.

5. Kartografię w działaniach oblężniczych zaczęto wykorzystywać od lat 60. XVI wieku. Wówczas Albrecht Hohenzollern wykonał przykładowy rzut izometryczny atakowanego miasta (il. 10). Z lutego 1568 roku pochodzi najstarszy zachowany plan oblężenia - dotyczył on zamku Uła, który był bez powodzenia oblegany przez Jana Chodkiewicza. Prawdopodobnym autorem tego planu był Maciej Stryjkowski (il. 15). Relacja Bartosza Paprockiego wskazuje na wykorzystanie mapy $\mathrm{w}$ działaniach taktycznych również w sierpniu 1568 roku. Wówczas Roman Sanguszko wykorzystał stary plan, który posłużył podczas rady wojennej jako podstawa planowania taktycznego. Na karcie głównodowodzący rozrysował stan fortyfikacji, na który nanosił miejsca ataku i innych podejmowanych przez dowódców działań. O powszechności tego rozwiązania pisze w latach 70. XVI wieku Stanisław Sarnicki. 
6. Odbudową spalonego zamku Uła zajął się Roman Sanguszko. Plan nowej fortyfikacji pochodzi z grafiki ULLA. Fortezza nel confin di Littuania (il. 17). Prawdopodobnym twórcą planów wykonanych jeszcze w 1563 roku był Włoch - Ambroży Gwagnin, zrealizowano je pięć lat później. Przebudowa Uły miała nastąpić w 1580 roku, jednakże wykonane plany rozbudowy zostały krytycznie ocenione przez Dominika Ridolfina i nie zrealizowano ich.

7. Wiedzę o praktycznym zastosowaniu kartografii wielkoskalowej rozpowszechniały dzieła typu Registrum huius operis libri cronicarum Hartmanna Schedla, Kosmografia Sebastiana Münstera czy Civitates orbis terrarum Georga Brauna i Fransa Hogenberga (il. 11-13). Wiadomo, że w 1548 roku Sebastian Münster wysyłał listy do Zygmunta Starego i możnowładców z prośbą o dostarczenie panoramy Gniezna oraz planu Krakowa ujętego w rzucie izometrycznym. Najstarszym tego typu planem miasta jest plan Wilna, opublikowany w trzecim tomie Civitates orbis terrarum z 1581 roku (il. 14). Należy podkreślić, że według Stanisława Sarnickiego umieszczane w publikacjach plany twierdz i miast stanowiły użyteczne źródło informacji dla dowódców planujących ich zdobycie.

8. Nowinki związane $\mathrm{z}$ inżynierią wojskową najczęściej docierały do Korony i Wielkiego Księstwa Litewskiego za pośrednictwem zatrudnionych specjalistów z Europy Zachodniej. Tych jednak, aż do początków panowania Stefana Batorego, było niewielu (m.in. Antonio Mora, Job Praytfuess). Wyróżniającym się inżynierem wojskowym, który pełnił również funkcję rotmistrza, był Ambroży Gwagnin. Życiorys Macieja Stryjkowskiego uprawdopodobnia przypuszczenie, że umiejętności wykonywania planów wielkoskalowych zawdzięcza Włochowi. Pierwszym na ziemiach polskich wysokiej klasy inżynierem wojskowym był służący u Stefana Batorego - Dominik Ridolfino. 


\section{Bibliografia}

\section{Źródła rękopiśmienne}

Санкт-Петербургский институт истории РАН, f. 32, karton 694, nr 1.

Archivio Segreto Vaticano, Segreteria di Stato, Polonia, sygn. 15A.

Archiwum Główne Akt Dawnych, Archiwum Publiczne Potockich, rkps 325, t. 1, Sarnicki S., Księgi hetmańskie.

Archiwum Główne Akt Dawnych, Archiwum Zamoyskich, sygn. 3112.

Archiwum Główne Akt Dawnych, Dokumenty pergaminowe, rkps 7789.

Archiwum Narodowe w Krakowie, Archiwum Sanguszków, Teki Rzymskie Sanguszków, teka XI/78.

Bayerische Staatsbibliothek, Rar 287.

Biblioteka Jagiellońska, rkps 171.

Biblioteka Kórnicka PAN, rkps 994, [Brożek J.], De Valentino Fontano et Grzepski. Biblioteka Książąt Czartoryskich w Krakowie, rkps 1813, Hohenzollern A., Księgi o rycerskich rzeczach a sprawach wojennych, przeł. M. Strubicz.

Biblioteka Książąt Czartoryskich w Krakowie, Teki Naruszewicza, sygn. 76.

Biblioteka Narodowa, sygn. 6609.

Biblioteka Uniwersytetu Warszawskiego, rkps 1954.

British Library, MS Harley, 1413, [Hohenzollern A.], Kriegsordnung bin ich genannt.

Muzeum Narodowe w Warszawie, nr inw. MP 2575.

Riksarkivet, Stockholm, Handritade kartverk, Bd. 28: Topographia practica. Conscripta et recognita per Fridericum Getkant mechanicum. Anno 1638.

Staatsbibliothek zu Berlin, Preußischer Kulturbesitz, Ms. boruss. fol. 1254, [Hohenzollern A.], Kriegsordnung bin ich genannt wer kriegt.

Staatsbibliothek zu Berlin, Preußischer Kulturbesitz, Ms. boruss. fol. 441, Hohenzollern A., Kriegsordnung bin ich genannt.

Vilniaus Universiteto Biblioteka, J. Lelevelio fondas: Atlasai, Tabulae geographicae Jacobi Gastaldi Pedemontani cosmographi aliquot aliorum 1559-1570 [...].

Zamek Królewski w Warszawie - Muzeum, Kolekcja dr. Tomasza Niewodniczańskiego, sygn. TN 5346 (dep. Deutsch-Polnische Stiftung Kulturpflege und Denkmalschutz).

\section{Źródła drukowane}

Albertrandy J.Ch., Panowanie Henryka Walezyusza i Stefana Batorego krolów Polskich, wyd. Z. Onacewicz, Kraków 1860.

Apian P., Instrument-Buch, Ingolstadt: [G. \& P. Apian], 1533. 
Archiwum XX. Sanguszków w Sławucie, t. 7: 1554-1572 (dyplomataryusz gałęzi Niesuchojeżskiej. T. 2), Lwów 1910.

Bielski M., Sprawa rycerska według postępku i zachowania starego obyczaju rzymskiego, greckiego, macedońskiego i innych narodow pierwszego i niniejszego wieku tak pogańska jako i krześcijańska $z$ rozmaitych ksiag wypisana ku czytaniu i nauce ludziom rycerskim pożyteczna, Kraków: Mateusz Siebeneicher, 1569.

Braun G., Hogenberg F., Civitates orbis terrarum, vol. I, Köln: Theodor Graminaeus, 1572.

Brożek J., Wybór pism, t. 1, oprac. H. Barycz, Warszawa 1956.

[Della Valle G.B.], Vallo libro continente appertinente [...], Vineggia: Piero Ravano, 1535.

Dürer A., Underweysung der Messung, mit dem Zirckel und Richtscheyt, in Linien, Ebenen unnd gantzen corporen, Nürnberg, [b. dr.],1525.

Dwa pedagogiczne traktaty polskie XVI-XVII wieku z Cesarskiej Biblioteki Publicznej w Petersburgu, wyd. Z. Bujakowski, w: Archiwum do dziejów literatury i oświaty $w$ Polsce, t. 14, Kraków 1914, s. 323-347.

Górnicki Ł., Dzieje w Koronie Polskiej od r. 1538 do r. 1572, wyd. K.J. Turowski, Sanok 1855.

Grzepski S., Geometria to jest miernicka nauka, wstęp H. Barycz, K. Sawicki i A. Siudut, Wrocław 1957.

Grzepski S., Geometria, to jest miernicka nauka, po polsku krótko napisana z greckich $i$ z łacińskich ksiag, Kraków: Łazarz Andrysowic, 1566 (reprint: Warszawa 1861).

Gwagnin A., Kronika Sarmacyjej Europskiej, Kraków: Mikołaj Lob, 1611.

Heidenstein R., De Bello Moscovitico commentariorum libri sex, Kraków: Drukarnia Łazarzowa, 1584.

Heidenstein R., Dzieje Polski od śmierci Zygmunta Augusta do roku 1594. Ksiag XII, t. 1, przeł. M. Gliszczyński, Petersburg 1857.

Hetman Florian Zebrzydowski o porzadku wojennym, wyd. S. Bodniak, „Przegląd Historyczno-Wojskowy" 3 (1931), z. 2, s. 295-305.

Kodeks wojskowy Piotra I z 1716 roku, oprac. i przeł. P. Krokosz, K. Łopatecki, Kraków-Oświęcim 2016.

Die Kriegsordnung des Markgrafen zu Brandenburg Ansbach und Herzogs zu Preussen Albrecht des Älteren - Königsberg 1555, Bd. 1-2, hrsg. von H.J. Bömelburg, B. Chiari, M. Thomae, Braunschweig 2006.

Król M., Geometria praktyczna, wyd. L. Birkenmajer, Warszawa 1895.

Księga ekspedycji kancelarii nadwornej 1559-1572. Materiały do dziejów dworu królewskiego, oprac. I. Kaniewska, Kraków 1997.

Lhor H., Kriegs Feldbüchlin von allerlay Schlachtordnungen welches in zehen tail getailet und ist bey einem jegklichen Büchlin sein sondere lehr, Dilingen: Sebaldum Mayer, 1569. 
Maricius S., De scholis seu academiis libri duo, Kraków: Hieronim Szarffenberg, 1551.

Marycjusz z Pilzna S., O szkołach czyli akademiach ksiag dwoje, przeł. A. Danysz, oprac. H. Barycz, Wrocław 1955.

Münster S., Cosmographia universalis, Basileae: Heinrich Petri, 1550.

Paprocki B., Herby rycerstwa polskiego, wyd. K.J. Turowski, Kraków 1858.

Pfinzing P., Methodus geometrica, Nürnberg: Valentin Fuhrmann, 1598.

Piotrowski J., Dziennik wyprawy Stefana Batorego pod Psków, wyd. A. Czuczyński, Kraków 1894.

Rewizja województwa połockiego z roku 1552, wyd. J. Szujski, w: Archiwum Komisyi Historycznej, t. 2, Kraków 1880, s. 173-256.

Sarnicki S., Księgi hetmańskie, oprac. M. Ferenc, Kraków 2015.

Schedel H., Registrum huius operis libri cronicarum cum figuris et imagibus ab inicio mundi, Nürnberg: Anthonius Koberger, 1493.

Starożytności historyczne polskie, t. 1, wyd. A. Grabowski, Kraków 1840.

Stryjkowski M., Kronika polska, litewska, żmudzka i wszystkiej Rusi, Królewiec: Georg Osterberg,1582.

Stryjkowski M., O wolności Korony Polskiej i Wielkiego Księstwa Litewskiego a o srogim zniewoleniu inszych królestw pod [...] jarzmem tureckim, Kraków 1575.

Tarnowski J., Consilium rationis bellicae, oprac. T.M. Nowak, Warszawa 1987.

Teksty opisowe Wilna, oprac. J. Fijałek, „Ateneum Wileńskie” 1 (1923), s. 506-526.

Zbiór pisarzów polskich, cz. 6, t. 17: M. Bielski, Kronika Polska, [t. 7], Warszawa 1832.

\section{Opracowania}

Казакоў А., Дзе адбылася Аршанская бітва 1514 2.?, „Герольд Litherland” 20 (2014), s. 4-29.

Alexandrowicz S., Kartografia Wielkiego Księstwa Litewskiego od XV do połowy XVIII wieku, Warszawa 2012.

Alexandrowicz S., Kartografia ziem Wielkiego Księstwa Litewskiego w epoce panowania Jagiellonów „Polski Przegląd Kartograficzny” 46 (2014), nr 1, s. 62-76.

Alexandrowicz S., Plan oblężenia zamku Uły z 1568 roku (przyczynek do początków staropolskiej kartografii wojskowej), „Polski Przegląd Kartograficzny” 18 (1986), nr 4, s. 165-175.

Alexandrowicz S., Rozwój kartografii Wielkiego Księstwa Litewskiego od XV do połowy XVIII wieku, Poznań 1989.

Alexandrowicz S., Buczek K., Polska kartografia wojskowa do połowy XVII wieku, w: Dzieje polskiej kartografii wojskowej i myśli strategicznej, materiały z konferencji, oprac. B. Krassowski, J. Madej, Warszawa 1982, s. 7-32.

Arnold T.F., Fortifications and the Military Revolution: The Gonzaga Experience, 1530-1630, w: The Military Revolution Debate. Readings on the Military Transformation of Early Modern Europe, San Francisco-Oxford 1995, s. 201-226. 
Balcerek M., Liczebność, skład i szyk wojska hetmana litewskiego Jana Karola Chodkiewicza w bitwie pod Kircholmem na ordre de bataille Erika Dahlberga, „Zapiski Historyczne. Kwartalnik poświęcony historii Pomorza" 74 (2009), z. 3, s. 77-92.

Bartoszewicz A., Bartoszewicz H., Dzieje kartografii miast polskich do końca XIX wieku. Zarys problematyki, „Polski Przegląd Kartograficzny” 45 (2013), nr 3, s. 236-255.

Barzmans K., Cartographic Line and the "Paper Management" of the Early Modern State: A Case Study of Venetian Dalmatia, „Mapline” 122 (2014), s. 1-15.

Białostocki J., Zagadka „Bitwy pod Orsza”, „Biuletyn Historii Sztuki” 17 (1955), nr 1, s. 80-98.

Bodniak S., Polska a Bałtyk za ostatniego Jagiellona, „Pamiętnik Biblioteki Kórnickiej" 3 (1946), s. 42-276.

Bogusławski J.K., Życia sławnych Polaków krótko zebrane, t. 2, Wilno 1814.

Buczek K., Dorobek kartograficzny wojen Stefana Batorego, „Wiadomości Służby Geograficznej" 8 (1934), z. 3, s. 3-15.

Buczek K., Kartografia polska w czasach Stefana Batorego, „Wiadomości Służby Geograficznej" 7 (1933), z. 2, s. 69-121.

Clausewitz C. von, O wojnie. Księga 1-5, przeł. A. Cichowicz, L. Koc, Warszawa 1958.

DeVries K., Gunpowder Weaponry and the Rise of the Early Modern State, „War in History" 5 (1998), issue 2, s. 127-145.

Dybaś B., Inżynier czy architekt? Uwagi o inżynierach wojskowych $w$ XVII-wiecznej Rzeczypospolitej, „Barok” 7 (2001), nr 1, s. 153-164.

Dzikowski M., Zbiór kartograficzny Uniwersyteckiej Bibljoteki publicznej w Wilnie, Wilno 1932.

Ferenc M., Dwór Zygmunta Augusta. Organizacja i ludzie, Oświęcim 2014.

Fijałek J., Opisy Wilna aż do połowy XVII wieku, „Ateneum Wileńskie” 1 (1923), s. 506-526.

Franczak G., Filologia mapy. Badanie dawnej kartografii metoda krytyki tekstu na przykładzie toponimii mapy Księstwa Połockiego S. Pachołowieckiego z 1580 roku, „Terminus” 19 (2017), z. 1 (42), s. 193-252.

Gębarowicz M., Początki malarstwa historycznego w Polsce, Wrocław 1981.

Gołaski J., Kształtowanie się mapy wsi w Polsce do końca XVIII w. Studium nad geneza wielkoskalowej informacji kartograficznej, Wrocław 1969.

Grabarczyk T., „Suchą stopq” czy „skacząc w fale”. Przekraczanie rzek przez wojska polskie od XI do poczatku XVI wieku, „Acta Universitatis Lodziensis. Folia Historica" 99 (2017), s. 83-109.

Hale J., Warfare and Cartography, ca. 1450 to ca. 1640, w: The History of Cartography, vol. 3: Cartography in the European Renaissance, part. 1, ed. D. Woodward, Chicago-London 2007, s. 719-737.

Hale J.R., The Early Development of the Bastion. An Italian Chronology, c. 1450c. 1534, w: Europe in the Late Middle Ages, ed. J. Hale, J.R. Highfield, B. Smalley, London 1965, s. 466-494. 
Herbst S., Walicki M., Obraz bitwy pod Orsza. Dokument historii sztuki i wojskowości XVI w., „Rozprawy Komisji Hist[orii] Sztuki i Kultury” (Warszawa) 1, (1949), s. 33-67.

Hniłko A., Plan bitwy pod Kircholmem Józefa Naronowicza-Narońskiego z r. 1659, „Przegląd Historyczno-Wojskowy” 7 (1934), z. 1, s. 126-133.

Homolicki M., O planach Wilna, jakiem było w XVI wieku, „Wizerunki i Roztrząsania Naukowe. Poczet Nowy Drugi” 24 (1843), s. 2-6.

Janicki M., Obraz Bitwa pod Orszą - geneza, datowanie, wzory graficzne a obraz bitwy „na Kropiwnej” i inne przedstawienia batalistyczne $w$ wileńskim pałacu Radziwiłtów, w: Bitwa pod Orszą, red. M. Nagielski, Warszawa 2015, s. 173-225.

Jasnowski J., Antoni Mora. Hiszpan w stużbie Zygmunta Augusta, „Przegląd Historyczno-Wojskowy" 9 (1936), z. 2, s. 305-306.

Kingra M.S., The Trace Italienne and the Military Revolution During the Eighty Years' War, 1567-1648, „Journal of Military History” 57 (1993), no. 3, s. 431-446.

Konczyńska W.A., List Sebastiana Münstera do Stanisława Łaskiego i garść szczegółów w związku z jego „Kosmografją”, Kraków 1936.

Kotarski H., Wojsko polsko-litewskie podczas wojny inflanckiej 1576-1582, cz. 1, „Studia i Materiały do Historii Wojskowości” 16 (1970), z. 2, s. 63-123.

Kotarski H., Wojsko polsko-litewskie podczas wojny inflanckiej 1576-1582, cz. 3, „Studia i Materiały do Historii Wojskowości” 17 (1971), z. 2, s. 81-151.

Kowalczyk J., Sebastiano Serlio a sztuka polska. O roli włoskich traktatów architektonicznych $w$ dobie nowożytnej, Wrocław 1973.

Lesmaitis G., Lietuvos Didžiosios Kunigaikštystès kariuomenès apžiūros Radaškovičiuose (1567) schema, „Lietuvos istorijos metraštis” (2010), z. 1 (wyd. 2011), s. $125-132$.

Łopatecki K., Poglądy Floriana Zebrzydowskiego dotyczące ufortyfikowania, obrony i poddania twierdz, „Białostockie Teki Historyczne” 13 (2015), s. 91-110.

Łopatecki K., Prace kartograficzne wykonane na ziemiach Rzeczypospolitej przez szwedzkich inżynierów wojskowych w XVII stuleciu, „Studia i Materiały do Historii Wojskowości” 46 (2009), s. 55-80.

Łopatecki K., Twórczość wojskowa Albrechta Hohenzollerna. Uwagi nad trzema manuskryptami przypisanymi w latach 2009-2014 Albrechtowi Hohenzollernowi, „Odrodzenie i Reformacja w Polsce” 59 (2015), s. 163-188.

Łopatecki K., Wyprawa zbrojna Krzysztofa Radziwiłła „Pioruna” w Inflantach zima 1579 roku, „Zapiski Historyczne” 83 (2018), z. 1, s. 39-67.

Łopatecki K., Walczak W., Mapy i plany Rzeczypospolitej XVII w. znajdujace się w archiwach w Sztokholmie. Maps and Plans of the Polish Commonwealth of the $17^{\text {th }} \mathrm{c}$. in Archives in Stockholm, t. 1, Warszawa 2011.

Łuczyński J., Miasta Rzeczypospolitej na planach $i$ widokach $w$ Civitates Orbis Terrarum Georga Brauna i Franza Hogenberga (rozważania nad treścia ikonograficzna), w: Dawna kartografia miast, red. J. Ostrowski, P.E. Weszpiński, Warszawa 2011, s. 59-83. 
McLean M., The Cosmographia of Sebastian Münster. Describing the World in the Reformation, Aldershot 2007.

Maisel W., Kaliska „Proporcyja łokci, prętów, morgów i włóki” z XVI w., „Kwartalnik Historii Kultury Materialnej” 17 (1969), nr 2, s. 259-260.

Marek M., Drzeworyt „Widok Krakowa od północy”, http://muzea.malopolska.pl/ obiekty/-/a/26855/1124880 (dostęp: 7.12.2017).

Maroszek J., Pogranicze Litwy i Korony w planach króla Zygmunta Augusta. Z historii dziejów realizacji myśli monarszej między Niemnem a Narwią, Białystok 2000.

Nestorow R., Jan Kampenhausen, inżynier na usługach hetmana Adama Mikołaja Sieniawskiego, w: Fides Ars Scientia. Studia dedykowane pamięci Księdza Kanonika Augustyna Mednisa, red. A. Betlej, J. Skrabski, Tarnów 2008, s. 319-360.

Nowak T.M., Cztery wieki polskiej książki technicznej 1450-1850, Warszawa 1961.

Nowak T.M., O zawodzie inżyniera wojskowego w Polsce XVII w., „Kwartalnik Historii Nauki i Techniki” 21 (1976), nr 3, s. 475-478.

Nowak T.M., Polska wersja „Porządku wojennego” Albrechta na tle stosunków polsko-pruskich, w: Die Kriegsordnung des Markgrafen zu Brandenburg Ansbach und Herzogs zu Preussen Albrecht des Älteren - Königsberg 1555, Bd. 1, hrsg. von H.J. Bömelburg, B. Chiari, M. Thomae, Braunschweig 2006, s. 147-156.

Nowak T.M., Problem stosowania broni palnej przy obronie i zdobywaniu umocnień przez wojska polskie w XVI-XVII w., „Studia i Materiały do Historii Wojskowości” 12 (1966), z. 1, s. 50-69.

Olejnik K., Stefan Batory 1533-1586, Warszawa 1988.

Olszewicz B., Geografia polska w okresie odrodzenia, Warszawa 1957.

Olszewicz B., Wzmianki o znaczeniu map w literaturze polskiej XVI wieku, „Acta Universitatis Wratislaviensis. Studia Geograficzne” 9 (1963), s. 129-140.

Parrott D., The Utility of Fortifications in Early Modern Europe. Italian Princes and Their Citadeles, 1540-1640, „War in History” 7 (2000), issue 2, s. 127-153.

Pepper S., Adams N., Firearms \& Fortifications. Military Architecture and Siege Warfare in Sixteenth Century Siena, Chicago 1986.

Plewczyński M., Kozacy w walkach z Moskwą nad Dźwina i Uła w latach 1567-1568, w: Od Kijowa do Rzymu. Z dziejów stosunków Rzeczypospolitej ze Stolica Apostolska i Ukrainą, red. M.R. Drozdowski, W. Walczak, K. Wiszowata-Walczak, Białystok 2012, s. 57-72.

Plewczyński M., Włosi w służbie koronnej za ostatnich Jagiellonów (1506-1572), „Studia i Materiały do Historii Wojskowości” 35 (1993), s. 301-309.

Pollak M., Cities at War in Early Modern Europe, Cambridge 2010.

Porter P., A Fresh Look at Harley MS. 1413: 'A Book ... fairly written in the German or Switz language', „The Electronic British Library Journal” 8 (2009), s. 1-12.

van Putten J., Networked Nation. Mapping German Cities in Sebastian Münster's 'Cosmographia', Leiden-Boston 2017.

Radziszewska J., Maciej Stryjkowski. Historyk-poeta z epoki Odrodzenia, Katowice 1978. 
Radziszewska J., Ze studiów nad turecka misją Macieja Stryjkowskiego, „Rocznik Biblioteki Naukowej PAU i PAN w Krakowie” 48 (2003), s. 31-55.

Sawicki K., Pięć wieków geodezji polskiej, Warszawa 1964.

Sinko T., Celtis Konrad, w: Polski słownik biograficzny, t. 3, Kraków 1937, s. 266-267.

Števík M., Zamek w Lubowli na tle średniowiecznych dziejów północnego Spiszu, „Rocznik Sądecki” 39 (2011), s. 27-52.

Szmytka R., Walka $z$ wiatrakami. Antyhiszpańskie powstanie w Niderlandach jako konflikt asymetryczny $w$ perspektywie historii środowiskowej, „Prace Historyczne" 143 (2016), s. 663-683.

Th.K., Dominik Ridolfino. Pułkownik w służbie Rzplitej polskiej w XVI wieku, „Przewodnik Naukowy i Literacki” 15 (1887), s. 732-748.

Turner A., Early Scientific Instruments. Europe 1400-1800, London 1987.

Voigt J., Des Herzogs Albrecht Kriegsstudien und Kriegsanstalten, „Neue Preußische Provinzialblätter” Serie III (Königsberg) 4 (1859), H. 1, s. 1-59.

Westra F., Nederlandse ingenieurs en de fortificatiewerken in het eerste tijdperk van de Tachtigjarige Oorlog, 1573-1604, Alphen aan den Rijn 1992.

Wojtkowiak Z., Maciej Stryjkowski, dziejopis Wielkiego Księstwa Litewskiego. Kalendarium życia i działalności, Poznań 1990.

Wrede M., Itinerarium króla Stefana Batorego 1576-1586, Warszawa 2010.

Zarębska T., Początki polskiego piśmiennictwa urbanistycznego, Warszawa 1975.

Żygulski Z., „Bitwa pod Orsza” - struktura obrazu, „Rocznik Historii Sztuki” 12 (1981), s. 85-132 